\title{
CCDO -94009644
}

FINAL REPORT

RECEIVED

MAR 211994

\section{ON PROJECT NUMBER OCDO/R-90-3DEPARTMENT OF DEVELOPMENT OHHO COAL DEV OFFICE}

\section{THE USE OF ETHANOL TO REMOVE SULFUR FROM COAL}

FOR THE PERIOD SEP'L'EMBER, 1991 TO DECEMBER, 1992

BY

\author{
THE OHIO COAL RESEARCH CENTER \\ OHIO UNIVERSITY \\ ATHENS, OH 45701
}

15 APRIL, 1993

REV. 10 MAR. 1994

\author{
PROJECT MANAGER: Dr. R.L. Savage 614/593-1500 \\ Emeritus Russ Professor 614/947-8996 \\ PROJECT PERSONNEL: Dr. L.K. LazarOV \\ Senior Research Associate \\ Dr. M.E. Prudich \\ Director, Ohio Coal Research Center \\ C.A. Lange \\ Part-time Technician \\ N. Kumar \\ Graduate Assistant
}

This project was funded in part by the ohio coal Development office, Department of Development, state of ohio.

Major co-sponsors of the project were the ohio corn Marketing Program Board, the National Corn Growers Association and the Kentucky Corn Growers Association. 
TABLE OF CONTENTS

EXECUTIVE BUYQTARY

Summary

Achievements

Page

FULI REPORT

Objective

Cosponsors

Previous work

Introduction

Technical Discussion

Work done under OCDO co-sponsorship

Description of the technology

Experimental procedure

Results

Discussion of results

Scale-up experiments

Selection of Ohio coals

Wastes and by-products

Changes in program and breakthroughs

Documentation

Marketing/Commercialization

Market potential

Estimated tonnages

Competing technologies

Next steps

Budget summaries

1

Appendix I Analyses of Ohio coals

26

Appendix II Tabulation of results of all

experiments during OCDO support $\quad 27$

\section{List of Figures}

Fig.1. -Laboratory apparatus

Fig.2 - Batch cross flow reactor

Fig.3 - Fluidized bed reactor

List of Tables

Table 1. -Selected autoclave experiments 10

Table 2. - Batch fluid bed reactor results 13

Table 3. -Ohio coal production by seams 17

Table 4. -Source of Ohio coal samples 18

Table 5. -sulfur content of five Ohio coals 19 


\section{EXECUTIVE SUMMARY}

Chemical removal of sulfur from coal is being studied using ethanol in the process. This report covers that portion of an on-going project which was funded in part by the Ohio Coal Development office (OCDO) from September, 1991 through February, 1993. Prior to the support by OCDO, the objective of the project was to verify and scale-up a process disclosed in U.S. Patent 4,888,029. This patent was assigned to southern I.linois University and the Illinois Geological survey. A memorandum of understariding between these organizations and ohio university included exchange of information and an agreement to negotiate a license to ohio University to license the patent on a commercial scale.

The long range goal of this project was to demonstrate that ethanol can be used to remove sulfur from coal. The short range, immediate objectives were to confirm that the process described in U.S. Patent $4,888,029$ would work on a laboratory scale of 5 to 20 grams of coal using etanol to remove sulfur from coal. If the laboratory experiments using methods described in U.S. Patent 4,888,029 were successful we were to attempt to scale up the experiments to one to ten pounds per batch or per hour. Because the laboratory experiments using the methods in U.S. Patent $4,888,029$ were not successful, the objective was changed to develop a new laboratory procedure to use etanol to remove sulfur from coal. This has been achieved.

The laboratory work in Illinois, on which U.S. Patent 4,888,029 was based, had been done using 50 to $100 \mathrm{milligrams}$ ( 0.050 to 0.100 grams) of powdered Illinois coal. The Illinois experiments were done in a thermogravimetric analyzer consisting of a miniature screen on which the powdered coal sample was placed in a heated vertical tube. The tube was heated to the desired temperature while ethanol vapors were carried up through the coal on the screen by helium plus nitric oxide gas. The loss in weight of the coal was measured and the off-gases were analyzed to detect the removal of sulfui from the coal. According to the patent, the pyrite in the coal served as a catalyst for the dehydrogenation of ethanol to form nascent hydrogen, a very reactive form of hydrogen. This active hydrogen could react with the sulfur in the coal to form hydrogen sulfide gas $\left(\mathrm{H}_{2} \mathrm{~S}\right)$ which could be recovered and marketed.

The attempts at ohio University to scale up U.S. Patent $4,888,029$ in the laboratory used 5 to 60 grams of coal in a stainless steel reactor. Results in the 105 laboratory experiments prior to OCDO support gave up to $90 \%$ removal of sulfur (down to $0.5 \% \mathrm{~S}$ ) from both ohio and Illinois coals with good reproducibility. However, as the work progressed we reached a point where we could not get more than $50 \%$ removal of sulfur and we concluded that the pyrite in the coal was not the critical catalyst for the process. In addition, we found that the conditions according to U, S, Patent $4,888,029$ do not assure an overcoming of the thermodynamic limitations of the pyrite reduction reactions, especially of the troilite (Fes) reduction.

While trying to determine why the results of the iaboratory experiments had changed, we developed a new laboratory procedure to use ethanol to remove sulfur from coal and other carbonaceous materials. It was found that copper was not only an effective catalyst for the reaction but also copper serves as a scavenger to remove the hydrogen sulfide as soon as it is formed and thereby prevent its contact with the desulfurized coal. 
In the work at Ohio University, 5 to 60 grams of pulverized coal were placed on a screen in the bottom of a copper cup suspended inside a stainless steel autoclave. The autoclave was heated to the desired reaction temperature $\left(400\right.$ to $\left.600^{\circ} \mathrm{C}\right)$ and a flow of ethanol vapors in helium plus $0.5 \%$ nitric oxide was introduced below the coal where the gases passed up through the coal and were vented from the autoclave. The sulfur content of the beginning coal and of the product coal was measured to determine the amount of sulfur removed from the coal during each experiment.

Achievements.

In developing the new ohio University procedure, the thermodynamic limitations of the reactions for removal of both pyritic and organic sulfur from coal at $400-600^{\circ} \mathrm{C}$ were studied using copper as a very strong $\mathrm{H}_{2} \mathrm{~S}-$ acceptor. Copper serves as a catalyst for ethanol dehydrogenation to form nascent hydrogen. Copper also serves as a scavenger to form copper sulfide from the hydrogen sulfide evolved during the reaction. Copper sulfide in turn serves as a catalyst for organic sulfur hydrodesulfurization reactions. If the coal to be desulfurized contains pyrite (Fes ${ }_{2}$ ) or Fes, the copper scavenger effect reduces any back reaction of hydrogen sulfide with the iron and increases the removal of sulfur from the carbonaceous material. The desired effect of using copper can be achieved by using copper or copper containing alloys as materials of construction or as liners for a regenerable reactor.

During the time period that OCDO supported this work, small scale (560 grams) laboratory experiments with coals containing about $3.5 \%$ sulfur have achieved up to $90 \%$ desulfurization at temperatures of $500^{\circ} \mathrm{C}$ when using a copper reactor. Results from the autoclave experiments have identified the nature of the chemical reactions taking place. Because the process removes both pyritic and organic sulfur in coal, the successful scale up of the process would have important economic significance to the coal industry. Even though this and other chemical processes may be relatively expensive and far from being commercial, the reason for further development is that this process may hold the promise of achieving much greater sulfur reduction and of producing a cleaner coal than other methods. This would be especially important for small or older power plants and industrial boilers.

The clean coal produced in the laboratory is a dry, finely pulverized powder suitable for direct firing in a pulverized coal boiler. However, until successful larger scale experiments have been completed, it is too early to make a meaningful projected timetable for the commercialization of the process, an estimate of operating costs, or the potential impact on the use of ohio coal.

Antici sated next steps.

The project is being continued with funding from other sources and a patent application has been filed for a new process. The technical work will develop the process on a laboratory scale and will scale up the operation to work with one to ten pound batches to get design and operating data for a pilot plant. 


\section{FULL REPORT}

INTRODUCTION.

The initial technical goal in the project was to develop a chemical method for the cost effective removal of both inorganic and organic sulfur from Ohio coals. Verifying and using a process of reacting ethanol vapors with coal under conditions disclossed in U.S.Patent $4,888,029$, the immediate technical objectives were to convert a small scale laboratory batch process to a larger scale continuous process which can serve as the basis for commercial development of the technology. This involved getting as much information as possible from small scale batch autoclave or fluid bed laboratory reactors for use in pilot plant studies. The laboratory data included material balances on the coal and sulfur, temperature and pressure ranges for the reaction, minimum reaction times at different conditions, the effectiveness of different activators such as oxygen and nitric oxide, the amount and nature of by-products such as sulfur dioxide, hydrogen sulfide and acetaldehyde, the effect of coal particle size on the speed and completeness of the reaction, and the effectiveness of the reaction on different Ohio coals.

Because the laboratory experiments using the method disclosed in U.S. $4,888,029$ were not successful, the objective for the project was changed to develop a new laboratory process to use ethanol to remove sulfur from coal. This has been achieved.

This project has been funded by the ohio corn Marketing Board in previous years for a total of $\$ 199,910$. from November, 1989 through December,1992; by the ohio coal Development office for $\$ 75,000$. from September, 1991 through December,1992; and by the National Corn Growers Association for $\$ 68,300$. from March, 1992 to February, 1993. Additional funds of $\$ 37,500$. for this project have been granted from the Kentucky corn Growers Association and additional matching funds from the ohio corn Marketing Board for $\$ 37,500$. A proposal to the National Corn Growers Association for $\$ 75,000$. is under consideration for April, 1993 through December, 1993. A pre-proposal was submitted to the Alternative Agriculture Research and Commercialization Center (AARC) but we were not invited to submic a full proposal because the project was still in the research stage rather than being ready for commercialization.

\section{TECHNICAL DISCUSSION}

\section{Previous Work}

Results during work on the project for two years prior to ocDo funding included over 105 laboratory autoclave experiments. Reproducible results for the removal of up to $90 \%$ of the sulfur from onio and Illinois coals were obtained using 5 to 20 grams of coal in each experiment. During this time period neither the investigators at the Illinois Geological survey (where the process was originally developed on a 50 milligram ( 0.050 gram) scale) nor at the Energy and Environmental center at Grand Forks, N.D. (using an autoclave similar to ours) could repeat our results. Investigators from these two laboratories had visited our facility to observe our operations and had taken samples of the cleaned coal to their laboratory for analysis. The analyses of the cleaned coal in their laboratory agreed with our analysis within $0.1 \%$ in the less than $0.5 \%$ sulfur range. 
Work under OCDO co-sponsorship

However, as work continued with OCDO co-sponsorship, the results in our laboratory changed dramatically. The percentage removal of sulfur from coal in the autoclave experiments dropped from the 80 to $90 \%$ range to the 30 to $40 \%$ range. An intense effort has been made to determine what change has caused the loss of effectiveness of the procedure as it was being used at that time, but no adequate explanation has been found.

During the period of previous work and the start of the work under OCDO co-sponsorship the results of sulfur removed from coal were measured only on the analysis of total sulfur in the coal before and after being processed in the autoclave. With $90 \%$ removal of total sulfur, we knew that both inorganic and organic sulfur were being removed, but we did not know how much of each. With the addition of a new staff member on the project, new information about the chemistry of the process was developed. The untreated coal and the product coal after treatment were analyzed for the different forms of sulfur. After a very thorough literature search (p 25) on reactions involving these forms of sulfur, Dr. Lazarov has developed an interpretation of the chemistry of the process which had not been in the patent disclosure and which explains the low desulfurization yields when attempting to use the methods of U.S. Patent 4,888,029. By gradually modifying the patented process we developed a new process with an interpretation of the chemistry as set forth below ( $p .4)$ The reactions are significantly different from those proposed in the original patent by Shiley (U.S. Patent 4,888,029) and will be the basis for filing a patent application on the new laboratory process.

A tabulation of the experiments which have been run during the period of funding by OCDO are attached as Appendix II ( $p 27$ ). The experiments using the new copper cup start with No.193. Independent verification of our results were obtained at the Center for Applied Energy Research in Lexington, KY in November, 1993, after the OCDO support had stopped. Their result of $0.88 \%$ sulfur in the char compared favorably with an ohio University result of $1.08 \%$ sulfur for the same coal and operating conditions.

\section{A Description of the Technology}

As a result of experiments using copper as a catalyst and as an $\mathrm{H}_{2} \mathrm{~S}$ scavenger, a new laboratory procedure to use ethanol to remove sulfur from coal has been developed at Ohio University and a patent application covering this process was filed in March, 1993. The process is based on the use of copper as a catalyst for the dehydrogenation of ethanol to produce nascent hydrogen to remove sulfur from the coal and the use of copper as a scavenger to capture the hydrogen sulfide formed from the sulfur removed from coal.

The thermodynamic limitations of the reactions for removal of both pyritic and organic sulfur from coal at $400-600^{\circ} \mathrm{C}$ both in an autogenous reductive atmosphere and in the presence of ethanol were studied using copper as a very strong hydrogen sulfide acceptor. Two substantial changes with respect to U.S. Patent 4,888,029 were introduced. A copper cup replaced a stainless steel cup as a reaction vessel mounted in a one liter autoclave and water was included also as a reactant fed in series with the ethanol. 
Treatment of coal at $400-600^{\circ} \mathrm{C}$ in the presence of copper and water vapors leads to an almost complete removal of inorganic sulfur. The removal of sulfur from pyrite proceeds in two steps. The first step, the reaction of pyrite $\left(\mathrm{FeS}_{2}\right)$ with gaseous hydrogen to form iron sulfide (Fes) has a favorable equilibrium constant above $380^{\circ} \mathrm{C}$ and can go nearly to completion [Eq.1]. The equilibrium constant for the second step to reduce Fes to $\mathrm{Fe}$ is not favorable $(\mathrm{K}<1)$ at temperatures up to $1000^{\circ} \mathrm{C}[\mathrm{Eq} .2$ ]. Therefore only half of the inorganic sulfur in the form of pyrite is removed by treating coal with gaseous hydrogen if $\mathrm{H}_{2} \mathrm{~S}$ is not removed very quickly from the reaction bed of coal. A reveresible reaction can run in an unfavorable direction if the concentration of the product is maintained very low, and if the reaction rate is sufficiently high. This is the case for $\mathrm{FeS}+\mathrm{H}_{2} \mathrm{O}$ to form $\mathrm{FeO}+\mathrm{H}_{2} \mathrm{~S}$ at $500^{\circ} \mathrm{C}$. in the presence of copper (Eq.3). By maintaining a very low concentration of hydrogen sulfide, the reaction can go substantially to completion within a reasonable time and can lead to an almost complete removal of inorganic sulfur.

\section{PYRITE REDUCTION}

$$
\begin{aligned}
& \mathrm{FeS}_{2}+\mathrm{H}_{2}-\mathrm{FeS}+\mathrm{H}_{2} \mathrm{~S} \\
& \mathrm{FeS}+\mathrm{H}_{2}-\mathrm{Fe}+\mathrm{H}_{2} \mathrm{~S}
\end{aligned}
$$

REACRION OF FES WITH $\mathrm{H}_{2} \mathrm{O}$

$$
\mathrm{FeS}+\mathrm{H}_{2} \mathrm{O}=\mathrm{FeO}+\mathrm{H}_{2} \mathrm{~S}
$$

While the inorganic sulfur removal is determined by the equilibrium of the ferrous sulfide reduction reaction, the organic desulfurization depends only on the kinetics of the reactions and their catalysis. If coal is pyrolysed at $400-600^{\circ} \mathrm{C}$ in the presence of copper and the vapor of a low molecular alcohol, eg. ethanol, up to $70 \%$ of the organic sulfur is removable. The alcohol dehydrogenates extensively under the catalytic influence of copper in these conditions to produce nascent hydrogen [Eq.4.] which reacts with the organic sulfur in the coal to form hydrogen sulfide $\left(\mathrm{H}_{2} \mathrm{~S}\right)$ [Eq.5]. The gaseous $\mathrm{H}_{2} \mathrm{~S}$ reacts with the copper in the reactor to form copper sulfide $\left(\mathrm{Cu}_{2} \mathrm{~S}\right)$ [Eq.6] as a result of the scavenging effect of the copper. The copper sulfide thus formed catalytically influences the hydrogenolysiss [Eq.5] of the organic sulfur-containing products of coal. The desired effect of using copper can be achieved by using copper or copper containing alloys as materials of construction or as liners for a regenerable reactor. Copper can be regenerated by roasting the sulfided copper with air at about $500^{\circ} \mathrm{C}$ [Eq.7] followed by reduction by hydrogen. The sulfur dioxide formed during regeneration could be converted directly to sulfuric acid.

ETHANOL DEHYDROGENATES TO ACETALDEHYDE AND NASCENT HYDROGEN

$$
\mathrm{C}_{2} \mathrm{H}_{5} \mathrm{OH} \quad \mathrm{CH}_{3} \mathrm{CHO}+2 \dot{\mathrm{H}}
$$


ORGANIC SULFUR GROUP HYDROGENOLYSIS

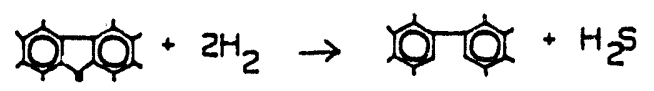

REACTION OF H 28 IN A COPPER REACTOR LEADS TO REGENERATION OF THE HYDROGEN CONSUMED

$2 \mathrm{Cu}+\mathrm{H}_{2} \mathrm{~S}+\mathrm{Cu}_{2} \mathrm{~S}+\mathrm{H}_{2}$

\section{THE REGENERATION OF THE CU 28 COVERING IS BY ROABTING VITH}

AIR AT 500-700 C.

$$
\mathrm{Cu}_{2} \mathrm{~S}+4 \mathrm{O}_{2} \rightarrow \mathrm{Cu}_{2} \mathrm{O}+\mathrm{CuO} \cdot \mathrm{CuSO}_{4}+\mathrm{SO}_{2}
$$

Using these reactions, in experiments with coals containing about $3.5 \%$ sulfur up to $90 \%$ desulfurization has been achieved at temperatures of $500^{\circ} \mathrm{C}$. Successful scale up of the process to commercial operation would allow the use of ohio coals to meet the strict acid rain restrictions which now prevent their use unless expensive wet scrubbers are installed and operated.

Because: our inability to duplicate the favorable autoclave results obtailed during the early months of 1991, the objective for the project was changed. Originally the plan was to run a selected coal in a batch stainless steel pipe reactor using two pounds of coal rather than the 5 to 10 grams used in the autoclave experiments. The objective was changed to a systematic evaluation of the reaction parameters in the autoclave to re-establish the reaction conditions needed to get good removal of sulfur from coal using ethanol. A complete and detailed knowledge of the operation parameters such as temperature, pressure, gas flow rate, amount and type of activator, amount and type of catalysts, materials of construction, reaction time, ratio to coal and number of portions of ethanol, water or hydrogen, and coal particle size, and kind of coal was needed for successful operation on a larger scale than the autoclave e:periments.

The successful development of a new laboratory procedure has been the result of a careful review of related literature, the application of thermodynamic and kinetic considerations and careful laboratory experiments to confirm the theoretical concepts and the use of copper as an $\mathrm{H}_{2} \mathrm{~S}$ acceptor.

The main conclusion is that more than $90 \%$ of the inorganic sulfur and about $70 \%$ of the organic sulfur can be removed from different coals using both ethanol and water as reactants (in series) at $500^{\circ} \mathrm{C}$. in a regenerable copper reactor. The sulfur removed from the coal is released as $\mathrm{SO}_{2}$ during the regeneration of the reactor. 
Experimental Procedure.

The batch one-liter stainless steel autoclave which has been used throughout the project was further modified to provide a copper cup, a copper thermocouple tube and a brass gas inlet tube which also suspends the copper cup inside the autoclave (Fig.1,p.8). Five grams of coal were placed on a copper perforated plate and screen about at the middle of the copper cup. By this arrangement, the incoming gases containing activator and ethanol or water vapors were in contact only with copper before contacting the coal. The coal and byproduct gases and vapors were in contact with the surface of the top part of the copper cup before being vented from the autoclave. During the heating up to a selected temperature, a constant flow of $60 \mathrm{ml} / \mathrm{min}$ of inert gas (helium) containing $0.5 \%$ NO (nitric oxide) as a reaction accelerator was driven through the reactor system.

Before the introduction of each portion of reactant (ethanol and/or water) the gas flow rate was reduced to $5-10 \mathrm{ml} / \mathrm{min}$ and maintained at this low level during the entire reaction residence time of the respective reactant. The total holding time at a given temperature was kept at 120 min. In practice, in the three portion experiments with 59 coal and reactant portions of $2.5 \mathrm{ml}(0.5 \mathrm{ml} / \mathrm{g}$ coal), each reactant was introduced for $5 \mathrm{~min}(0.5 \mathrm{ml} / \mathrm{min})$ and treated for $25 \mathrm{~min}$ at a reduced gas flow rate of $5-10 \mathrm{ml} / \mathrm{min}$. Between the portions (two intervals of $15 \mathrm{~min}$ ) a higher gas flow rate of $80-150 \mathrm{ml} / \mathrm{min}$ was resumed when the pressure reverted to its initial level ( $50 \mathrm{psig})$. In the case of the two portion experiments with $5 \mathrm{~g}$ coal and reactant portions of $5 \mathrm{ml}$ ( $1 \mathrm{ml} / \mathrm{g}$ coal), each reactant was introduced for $5 \mathrm{~min}(1 \mathrm{ml} / \mathrm{min}$ ) and treated for $45 \mathrm{~min}$ at a reduced gas flow rate of 5-10 $\mathrm{ml} / \mathrm{min}$. During an interval of $20 \mathrm{~min}$ between the portions a higher gas flow rate of $80-150 \mathrm{ml} / \mathrm{min}$ was maintained until the pressure reverted to its initial level of 50 psig after having increased to $>200$ psig during the addition of reactants.

For the regeneration of the copper reactor successive treatments (blowing through) with air $(80 \mathrm{ml} / \mathrm{min})$ at $500^{\circ} \mathrm{C}$. and with hydrogen (30 $\mathrm{ml} / \mathrm{min}$ ) at $200^{\circ} \mathrm{C}$. Were applied. The bulk of the sulfur, retained in the sulfide layer, was burned off for 30 minutes but the roasting continued

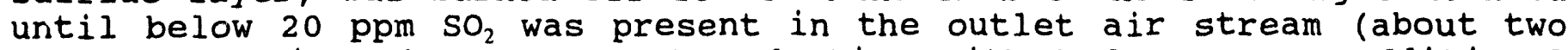
hours). During the subsequent reduction with hydrogen, an additional amount of $\mathrm{SO}_{2}$ was produced. A 30 minute reduction was usually applied. After regeneration, the reactor was dismantled and cleaned by means of an air jet in preparation for the next run. 


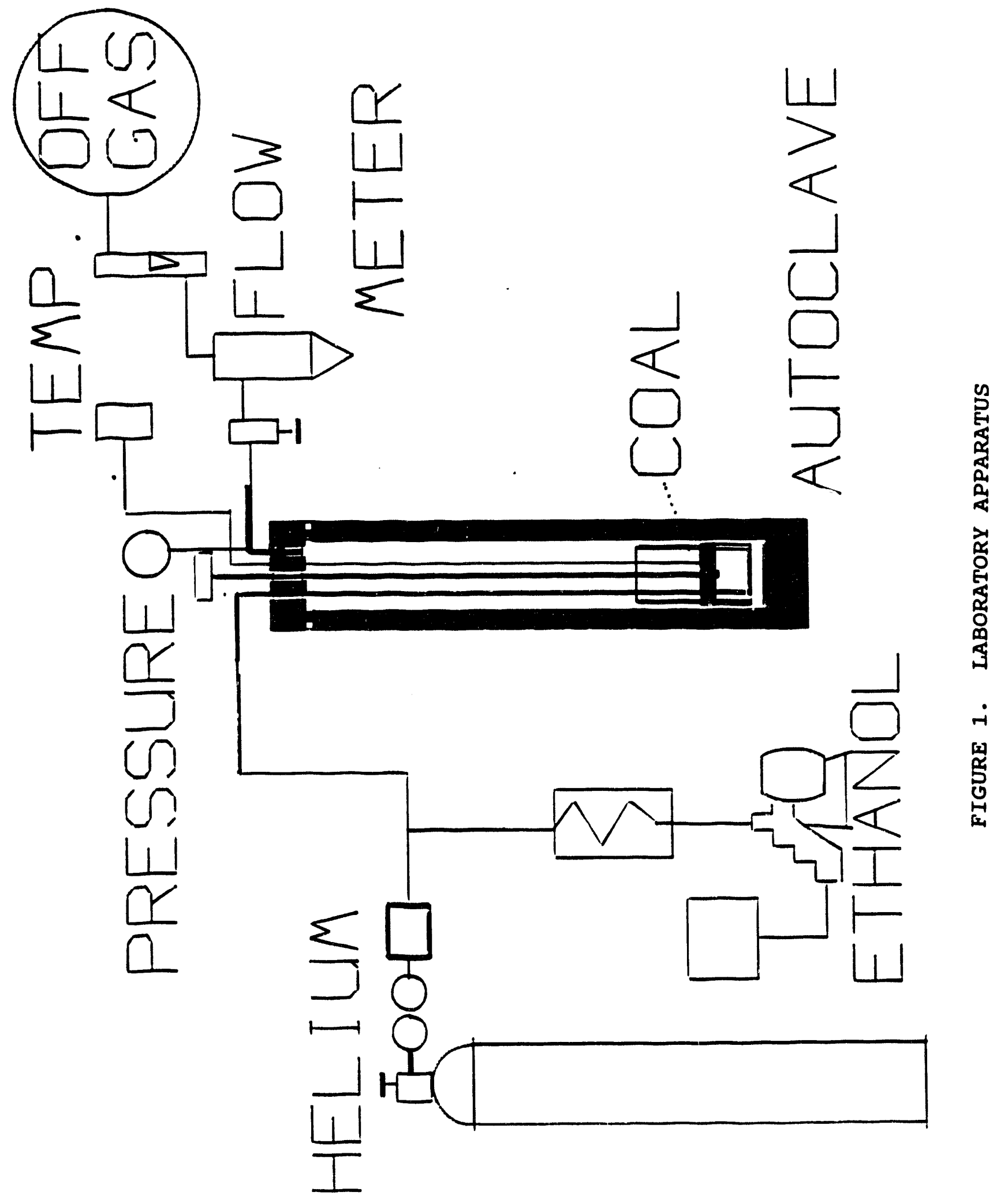


Three Ohio high-volatile bituminous coals were used in these experiments. They were a sample of ohio \#6 (Middle Kittanning) coal obtained from the Penn state Coal Bank (PSOC-1518) and two washed samples (Ohio \#4A and \#11), collected from Sands Hill and Marietta Coal Companies, respectively. The sulfur analyses of these coal samples are as follows.

\begin{tabular}{lllll}
\hline Coal & $\begin{array}{l}\text { Total } \\
\text { Sulfur } \\
\text { Percent, Dry Basis }\end{array}$ & $\begin{array}{l}\text { Pyritic } \\
\text { Sulfur }\end{array}$ & $\begin{array}{l}\text { Sulfate } \\
\text { Sulfur }\end{array}$ & $\begin{array}{l}\text { Organic } \\
\text { Sulfur } \\
\text { (by difference) * }\end{array}$ \\
\hline PSOC-1518 & 3.7 & 0.9 & $1.1 *$ & 1.7 \\
Ohio \#4A & 4.0 & 2.0 & 0.0 & 2.0 \\
Ohio \#11 & 2.5 & 0.9 & 0.5 & 1.1
\end{tabular}

\footnotetext{
* This sulfate sulfur content indicates some oxidation of the sample.

** Total S - Pyritic $S$ - Sulfate $S$ = organic $s$

Total sulfur was determined by a Leco SC32 combustion analyzer

Pyritic sulfur was determined by the wet chemical method in ISO 157-1975 (International Organization for standardization)

sulfate sulfur was determined by ASTM 2492 .
}

The apparent $\%$ sulfur removed as listed in the Table of Experiments in Appendix I was calculated by the following formula which does not take into account the weight loss of the coal during the experiment.

$$
\text { Apparent o Sulfur Removed }=\frac{8 \text { Initial } S-8 \text { Final } S}{8 \text { Initial } S} * 100
$$

The real (actual) \% sulfur removed takes into account the loss in weight of the coal in the autoclave during the heating period. It was calculated by the following formula.

$$
\text { Actual of } s \text { removed }=\frac{\text { f Initial } s-\left[\frac{q \text { Final } s * 100-W t . \text { Loss }}{100}\right]}{8 \text { Initial } S} * 100
$$

\section{Results}

The important results from PSOC-1518 (Ohio \#6) and ohio \#4A are presented in Table 1. (p.10). A tabulation of all runs conducted during the period of OCDO support for the project is in Appendix II (p.27) 
TABLE 1. TABULATION OF SELECTED NUTOCLAVE EXPERIMENTS

\begin{tabular}{|c|c|c|c|c|c|c|c|c|c|c|}
\hline$\#$ & COAL & $\begin{array}{l}\text { TEMPERATURE } \\
{ }^{\circ} \mathrm{C}\end{array}$ & REACTOR & GAS FLOW & $\begin{array}{c}\text { REACTANT } \\
\text { \# OF } \\
\text { PORTIONS }\end{array}$ & $\begin{array}{c}X S \\
\text { IN } \\
\text { THE } \\
\text { COAL }\end{array}$ & $\begin{array}{l}\text { X s } \\
\text { IN } \\
\text { THE } \\
\text { PRODUCT }\end{array}$ & TOTAL $\quad$ X DE & $\begin{array}{l}\text { ESULFURIZ } \\
\text { INORGANIC }\end{array}$ & $\begin{array}{l}\text { ATION } \\
\text { ORGANIC }\end{array}$ \\
\hline 138 & PSOC 1518 & 450 & $\begin{array}{c}\text { Stainless } \\
\text { steel }\end{array}$ & nitrogen & $\begin{array}{l}\text { no } \\
\text { reactant }\end{array}$ & 3.61 & 2.73 & 41.3 & 47.7 & 31.2 \\
\hline$\overline{160}$ & $\pi$ & "1 & $\pi$ & $\begin{array}{l}\mathrm{He}+0.5 \% \\
\text { NO }\end{array}$ & $\begin{array}{l}\text { Ethanol } \\
3 \text { portions }\end{array}$ & 3.57 & 2.39 & 47.3 & 44.2 & $\overline{51.4}$ \\
\hline 189 & "1 & 460 & $\begin{array}{l}\text { copper, } \\
\text { non-sulfided }\end{array}$ & d & 11 & 3.65 & 1.52 & 69.2 & 78.8 & $\overline{60.1}$ \\
\hline$\overline{185}$ & $\overline{11}$ & $"$ & $\begin{array}{l}\text { copper, } \\
\text { sulfided }\end{array}$ & 7 & 11 & 3.83 & 1.27 & $\sqrt{5.1}$ & 80.6 & $\overline{68.1}$ \\
\hline 195 & $\begin{array}{l}\text { Ohio } 4 \text { A } \\
-20 \text { mesh }\end{array}$ & 480 & 11 & 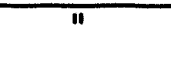 & $\begin{array}{l}\text { no } \\
\text { reactant }\end{array}$ & 3.97 & 3.08 & 46.3 & 65.3 & 27.9 \\
\hline$\overline{197}$ & "1 & 7 & " & nitrogen & $\begin{array}{l}\text { Ethanol, } \\
3 \text { portions }\end{array}$ & 3.76 & 2.38 & 57.7 & & \\
\hline$\overline{194}$ & " & 7 & " & $\mathrm{He}+0.5 \mathrm{XNO}^{2}$ & " & 3.86 & 2.06 & 63.5 & 66.8 & 60.2 \\
\hline$\overline{198}$ & 11 & $\overline{11}$ & $\pi$ & hydrogen & $\begin{array}{l}\text { no } \\
\text { reactant }\end{array}$ & 3.90 & 2.43 & 59.2 & 54.6 & 63.9 \\
\hline 200 & $\begin{array}{l}\text { Ohio \# } 4 \text { A } \\
-100 \text { mesh }\end{array}$ & 7 & 11 & $\begin{array}{l}\mathrm{He}+0.5 \% \\
\mathrm{NO}\end{array}$ & $\begin{array}{l}\text { Ethanol, } \\
3 \text { portions }\end{array}$ & 3.72 & 1.56 & 69.6 & 69.9 & 69.4 \\
\hline 204 & $\begin{array}{l}\text { Ohio \#11 } \\
-100 \text { mesh }\end{array}$ & " & $\pi$ & " & $\pi$ & 2.41 & 0.78 & $76 . \overline{3}$ & & \\
\hline$\overline{202}$ & $\begin{array}{l}\text { Ohio \#4A } \\
-100 \text { mesh }\end{array}$ & 500 & $\pi$ & 11 & $\begin{array}{l}\text { Ethanol, } \\
2 \text { portions } \\
\text { water, } 1 \\
\text { portion }\end{array}$ & 3.64 & 0.98 & 82.5 & 90.4 & 72.9 \\
\hline$\overline{206}$ & $\begin{array}{l}\text { Ohio \#4A } \\
-100 \text { mesh }\end{array}$ & 500 & $\begin{array}{l}\text { copper, } \\
\text { sulfided }\end{array}$ & $\mathrm{H}+0.5 \%$ & $\begin{array}{l}\text { Ethanol, } \\
2 \text { portions } \\
\text { Water, } \\
1 \text { portion }\end{array}$ & 3.80 & 0.98 & 82.7 & 93.2 & $\overline{72.6}$ \\
\hline$\overline{209}$ & " & " & " & " & $\pi$ & 3.80 & 0.55 & 90.4 & & \\
\hline 208 & $"$ & $"$ & $"$ & $"$ & $\begin{array}{l}\text { Water, } \\
1 \text { portion } \\
\text { Ethanol, } \\
1 \text { portion }\end{array}$ & 3.73 & 1.01 & 81.5 & 93.6 & 69.0 \\
\hline-212 & " & 1 & 11 & $"$ & $\begin{array}{l}\text { Water. } \\
1 \text { portion**} \\
\text { Ethanol. } \\
1 \text { portion** }\end{array}$ & 3.86 & 0.71 & 87.95 & & \\
\hline $2 \overline{214}$ & iv & " & $"$ & 11 & $\begin{array}{l}\text { Water, } \\
1 \text { portion** } \\
\text { Hydrogen- } \\
\text { gas-1 porti } \\
(0.1 \text { mo1) }\end{array}$ & 3.87 & 1.36 & 78.3 & 88.6 & 68.0 \\
\hline
\end{tabular}

* Double the amount of reactant portions $(1 \mathrm{ml} / \mathrm{gm}$ coal ) were added.

Total sulfur was determined by a Leco SC32 combustion analyzer

Pyritic sulfur was determined by the wet chemical method in iso

(International Organization for Standardization)

$157-1975$

Sulfate sulfur was determined by ASTM 2492.

Total S - Pyritic S - Sulfate $S=$ Organic $S$ 


\section{Discussion of Results.}

The autoclave experiments included in Table 1 were selected to demonstrate the conditions, reactants and materials of construction needed to achieve successful removal of sulfur from coal using ethanol as a source of active hydrogen to react with the sulfur in the coal.

Experiments 138 and 160 demonstrate the low removal of sulfur from coal when using a stainless steel autoclave with no copper present and with or without ethanol present as a reactant, $41.3 \%$ and $47.3 \%$ desulfurization. Experiment 160 can be considered as corresponding to the conditions disclosesd in U.S. Patent 4,888,029.

In experiments 189 and 185 the improved removal of sulfur from the coal is demonstrated due to the presence of copper in different forms, $69.2 \%$ and $75.1 \%$ desulfurization.

Experiment 195 shows the low level of desulfurization of the coal in the absence of a source of hydrogen (either ethanol or water). This is the amount of desulfurization resulting from just heating the coal to $480 \mathrm{C}$, 46.3\% desulfurization.

Experiment 197 shows the limited effect of ethanol in the absence of an activator such as $0.5 \%$ NO, $57.7 \%$ desulfurization.

Experiments 194 and 198 compare the amount of desulfurization with ethanol, 63.5\%, and gaseous hydrogen under the same operating conditions, $59.2 \%$.

Experiments 200 to 212 show the effects of variations of the amounts of ethanol or water or combinations of the two on the amounts of desulfurization of ohio coals. The results range from $69.6 \%$ to $90.4 \%$ total sulfur removal. These results do not reflect a scatter of results from duplicate experiments but rather the effects of intentional variations in reactants or operating conditions and consequently an average of the results would have no significance. They do demonstrate that, at $500^{\circ} \mathrm{C}$ with copper as the material of construction and ethanol and water as the reactants, up to $90.4 \%$ total desulfurization of ohio coals can be achieved.

Experiments 214 and 212 show again that the use of gaseous hydrogen with water is not so effective as ethanol and water, $87.9 \%$ versus $78.3 \%$ total desulfurization.

Reproducible laboratory autoclave experiments now can be made to produce low sulfur coal. However, attempts to operate the process in larger scale equipment have not been successful. 
Scale-up Experiments.

A batch fluidized bed reactor (Fig.3, p.16) was operated to test the effectiveness of a fluidized bed for contacting the ethanol vapors with the coal. In the batch mode, the unit was heated to reaction temperature with a flow of nitrogen at a rate required to fluidize the coal. A cold-flow model, a clear plastic pipe, had been used to determine the minimum gas flow required to fluidize the coal particles. As soon as the fluidized bed unit reached reaction temperature, a charge of coal was introduced through the feed pipe and allowed to heat to reaction temperature. The gas flow was then be switched to nitrogen plus activator ( $0.5 \%$ nitric oxide or $1.5 \%$ oxygen) and the ethanol vapors were pumped into the reactor below the distribution screen for a predetermined period of time, then the coal was discharged through the outlet pipe for analysis for sulfur. Gas samples were collected and analyzed for $\mathrm{H}_{2} \mathrm{~S}$. In this unit a series of experiments, using one, two and four pounds of coal to get different contact times and three different amounts of ethanol to observe the minimum alcohol requirement could be run. If the results were favorable, then the fluid bed unit could be operated to simulate a continuous flow fluid bed reactor over a period of time by sequentially adding coal through the top hopper and removing coal through the bottom hopper. At a later date, units could be added to provide continuous feed and continuous discharge of the coal.

A batch cross-flow reactor (Fig.2,p.15) was operated to determine if this type of reactor will result in uniform sulfur removal from the coal biing tested. Similar in operation to the autoclave experiments, two pounds of coal were charged into the screen basket, the unit assembled, and the unit heated to temperature with a flow of nitrogen. As soon as the coal in the basket reached the desired reaction temperature, the gas flow was switched to nitrogen plus activator ( $0.5 \%$ nitric oxide or $1.5 \%$ oxygen) and ethanol vapors were pumped through the cross-flow bed. Gas samples were collected for analysis of $\mathrm{H}_{2} \mathrm{~S}$. After the unit was cooled, the reactor was opened, and the coal removed for weighing and for analyzing for sulfur.

For a batch mode of operation of the fluid bed unit to simulate a larger scale autoclave experiment, a 3-inch $0 . d$. copper cup with a perforated bottom plate was inserted into the bottom of the reactor to a position where the bottom layer of coal was at the mid-point of the bottom heater. The reactor was heated to the operating temperature and the charge of $-20+100$ mesh coal was dropped into the copper cup. The activator gas, nitrogen plus $1.5 \%$ oxygen, and ethanol vapors were preheated to $290-300^{\circ} \mathrm{C}$ in the lower gas pre-heater section of the unit and introduced into the reactor below the perforated bottom of the copper cup. At the end of the run, the reactor was unbolted from the gas preheated section and the copper cup containing the treated coal was withdrawn from the bottom of the reactor. Treated coal from the top third, middle third and bottom third of the cup was collected and analyzed separately. All runs were at atmospheric pressure and the average starting value of the raw coal was $3.31 \%$ sulfur. The results follow. 
TABLE 2. BATCH FLUID BED REACTOR

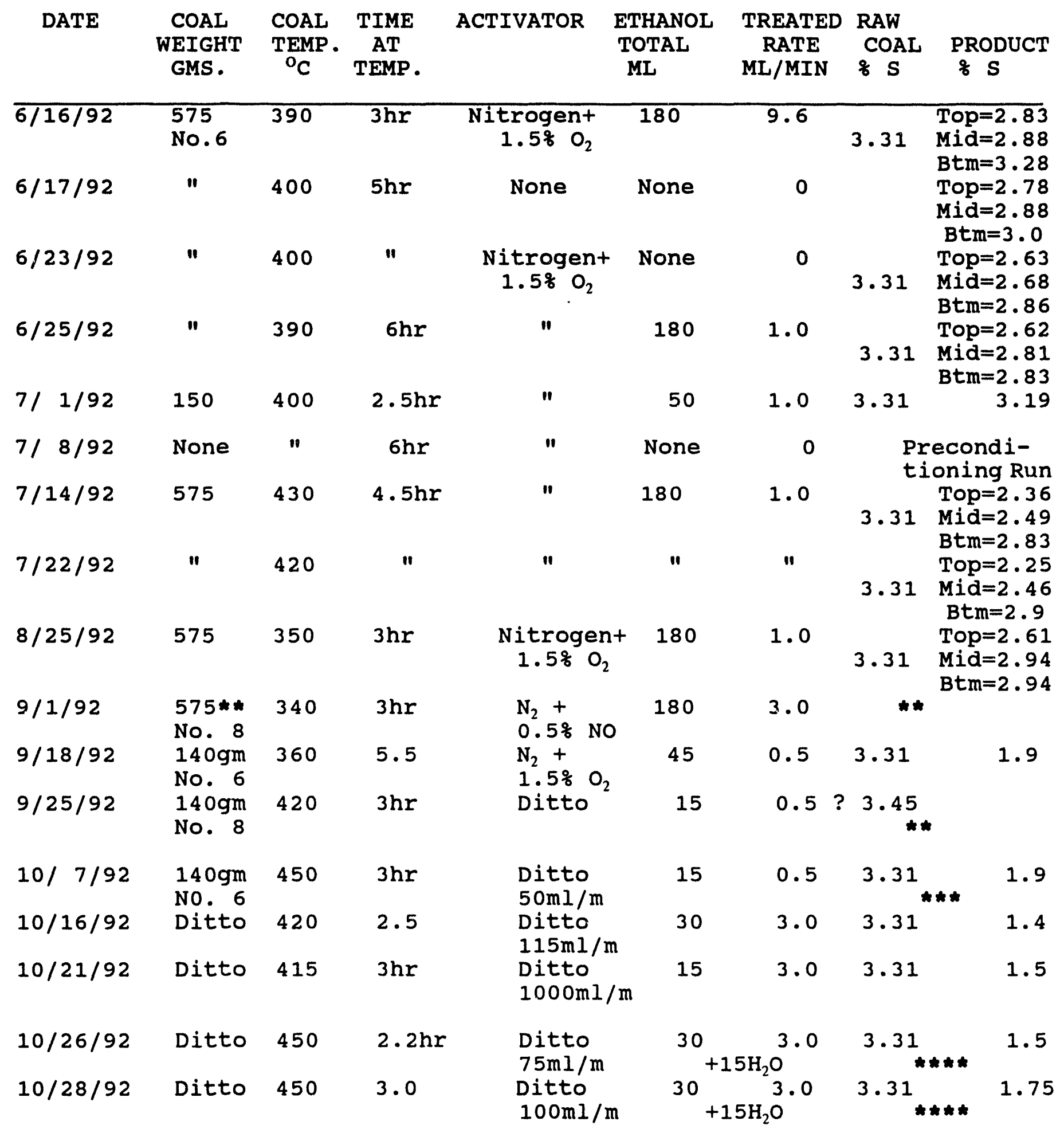

* * Pittsburgh No.8 coal has a high free swelling index (FSI) of 6 to 8 and was coked into a solid mass in the cup.

*** The following runs were attempts to duplicate the conditions the successful autoclave experiments.

Alternate injections of $15 \mathrm{ml}$ EtoH and $\mathrm{H}_{2} \mathrm{O}$ 
The necessary sections of flanged stainless steel pipe and tubing were on hand to assemble each of the reactors. Additional controllers, on line gas analyzers and data acquisition units were purchased or adapted to this use. All of these were selected so that they can be used on the continuous reactor when it is assembled.

Various configurations of the batch fluid bed reactor and the batch cross-flow reactor were examined to get the best control of the temperature of the coal in the reaction zone and the best preheat of the gas and alcohol vapors. Because of non-uniform heating along the reactor wall, new heaters were installed on the reactor section of the batch fluid bed unit. Three six-inch cylindrical heaters, each with a separate temperature controller, were used. Tests using separate thermocouples inserted at the mid-point of each heater showed uniform wall temperatures for each heater section.

As in the batch autoclave experiments, the test procedures consisted of weighing the raw coal, analyzing the raw coal for sulfur, measuring gas flow, temperature and pressure during the reaction, sampling and analyzing the off-gas stream for hydrogen sulfide, weighing the product coal, and analyzing the product coal for sulfur.

None of the product coals were within a sulfur range that would make them a compliance coal. The difference in sulfur level between the top of the product sample and the bottom of the sample is yet to be explained. Until the conditions used for successful results in the autoclave experiments can be duplicated in the fluid bed or the cross flow batch reactor to get 80 to 90 per cent removal of sulfur from the coal, we cannot make a decision on which type of reactor will be the better choice. Work with these two reactors will continue during 1993 under different sponsors. 
FIG. 2

BATCH CROSS FLOV REACTOR

OHIO UNIV. 9/9g RLS

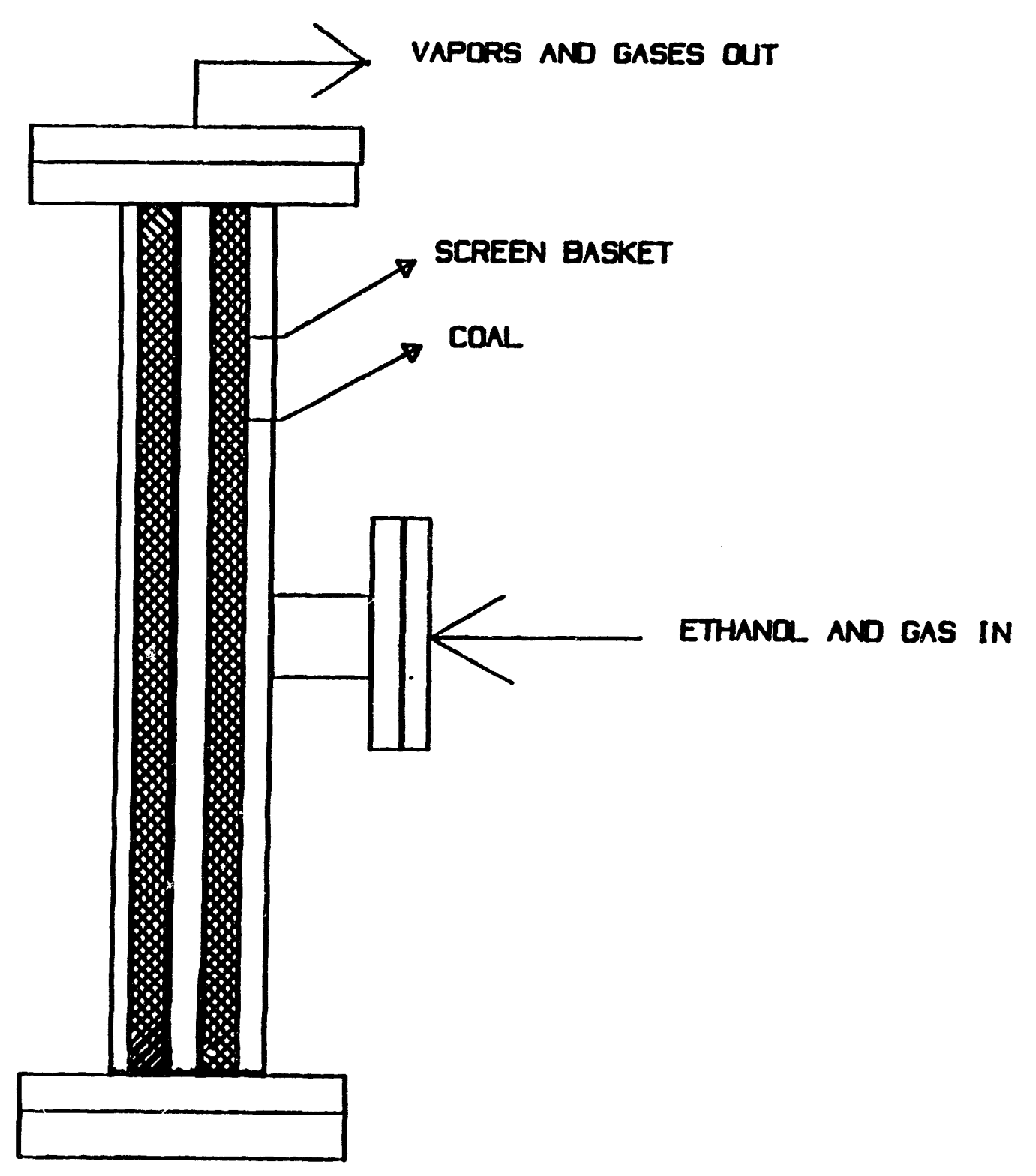


Y L

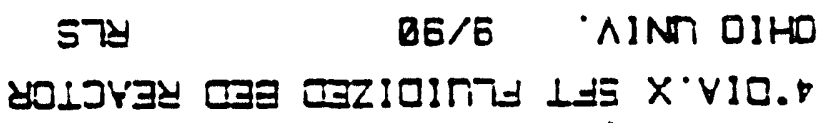

E.

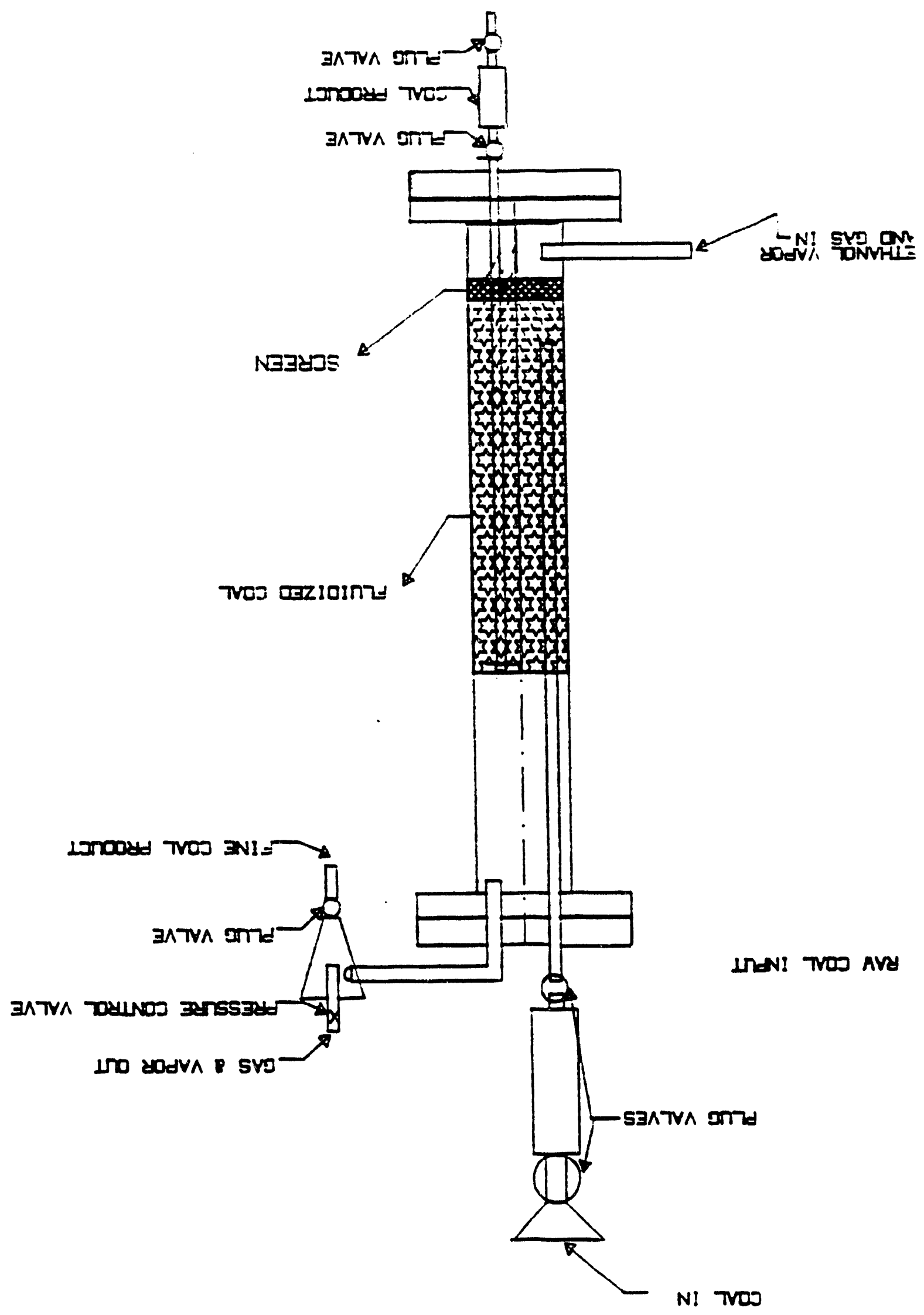


Selection of ohio coals

During the initial work on this prozess, an ohio No. 6 coal from the Middle Kittanning seam was used to investigate the effectiveness of the process. In order to permit other investigators to use the same coal, a sample of the ohio No. 6 seam was obtained from the Penn state Coal Sample Bank and is identified as PSOC-1518. This was a whole seam channel sample taken in Carroll county. Reported sulfur content of the coal in the sample is $3.86 \%$.

It was considered important to determine what other ohio coals can be used as feed stock for the process to use ethanol to remove sulfur from coal. Because of the possible in situ catalytic effect of pyrite in the coal, the amount and distribution of pyrite in different coals may be an important factor in the suitability of a particular coal for use in the desulfurization process, but this has not been found to be the case.

Based on the 1988 production figures, coal samples from the five highest tonnage seams in ohio were collected and tested for sulfur removal using ethanol as the reactant. Sample selection was based on the following table:

TABLE 3. OHIO COAL PRODUCTION BY COAL SEAMS

\begin{tabular}{|c|c|c|c|}
\hline Priority & Coal seam & Counties & 1988 tonnage \\
\hline 1 & No.8 Pittsburgh & $\begin{array}{l}\text { Belmont, } \\
\text { Harrison, } \\
\text { Jefferson, } \\
\text { Monroe }\end{array}$ & $7,598,745$ \\
\hline 2 & No.9 Meigs Creek & $\begin{array}{l}\text { Belmont, } \\
\text { Noble }\end{array}$ & $5,614,248$ \\
\hline 3 & No.4A Clarion & $\begin{array}{l}\text { Jackson, } \\
\text { Meigs, } \\
\text { Vinton }\end{array}$ & $5,526,633$ \\
\hline 4 & $\begin{array}{l}\text { No. } 6 \text { Middle } \\
\text { Kittanning }\end{array}$ & $\begin{array}{l}\text { Columbiana, } \\
\text { Coshocton, } \\
\text { Perry, } \\
\text { Tuscarawas }\end{array}$ & $3,979,549$ \\
\hline 5 & $\begin{array}{l}\text { No. } 5 \text { Lower } \\
\text { Kittanning }\end{array}$ & $\begin{array}{l}\text { Coshocton } \\
\text { Jackson, } \\
\text { Stark, } \\
\text { Tuscarawas, } \\
\text { Vinton }\end{array}$ & $2,581,480$ \\
\hline $\begin{array}{l}6 \\
7\end{array}$ & $\begin{array}{l}\text { No. } 11 \text { Waynesburg } \\
\text { No. } 7 \text { Upper } \\
\text { Freeport }\end{array}$ & $\begin{array}{l}\text { Belmont } \\
\text { Coshocton } \\
\text { Harrison } \\
\text { Tuscarawas }\end{array}$ & $\begin{array}{l}1,430,089 \\
1,027,384\end{array}$ \\
\hline 8 & No. 4 Brooksville & $\begin{array}{l}\text { Columbiana } \\
\text { Mahoning, } \\
\text { Stark, } \\
\text { Vinton }\end{array}$ & 976,247 \\
\hline
\end{tabular}


Two five-galion samples of each of the top five coals have been collected. The samples needed for this project are production samples of washed coal in current production.

During a meeting to discuss the ethanol process, Robert Lenko of the Cravat coal Company volunteered to locate sources of samples of the desired coals. Based on the information and help by Mr. Lenko, we have collected two 5-gallon plastic cans of each of the following coals:

\section{TABLE 4 - BOURCE OF OHIO COAL BAMPLES}

No.8 coal seam -Ohio Valley Coal Co.

Belmont County, cleaned in Jeffry Baum Jig washed to $1.6 \mathrm{sp} . \mathrm{gr}$. Ohio Mine \# Bt-68

No.9 coal seam -Marietta Coal Co.

Belmont County, Pit \#702, Ohio Mine \#Bt-

Washed, $3 / 4 \times 0$, heavy media \& $1.6 \mathrm{sp.gr}$.

No.4A coal seam-Sands Hill Coal Co.

Vinton County, Sugar Run Mine

Washed, $3 / 4 \times$ ?

No. 6 coal seam-Crooksville coal Co.

Perry County, Bearfield Twp., Sec3, State Min No.Py -317 .

Washed, heavy media @ sp.gr. 1.45,

$11 / 2 \times 1 / 2$.

No.11 coal seam-Marietta coal Co.

Belmont Co.,Pits 758-798, Ohio Mine \#Bt-1104 Washed, $3 / 4 \times 0$, heavy media a $1.6 \mathrm{sp} g r$.

Using the samples of the five Ohio coals collected, each sample was processed and tested as follows:

1.Air dry one 5-galion sample overnight at $105 \mathrm{C}$.

2. Split and retain $1 / 4$ of sample.

3. Crush retained sample to minus $1 / 4$ inch in Chipmunk jaw crusher.

4. Reduce minus $1 / 4$ inch sample to minus 20 mesh in disc mill.

5. Split and retain one pound of minus 20 mesh coal.

6. Pulverize to minus 200 mesh coal in wiley impact mill.

7. Screen pulverized coal through 200 mesh Tyler screen in a RoTap shaker.

8. Retain minus 200 mesh coal as raw coal for autoclave experiments.

Using conditions as established in previous experiments on ohio No. 6 coal (PSOC-1518), each minus 200 mesh coal sample was run in the autoclave configured as in Fig. $1,(\mathrm{p} .8)$. 
Raw coal was analyzed for sulfur, ash, volatile, fixed carbon, moisture and Btu. Ten of coal grams were charged into the autoclave. A.c the end of the experiment, the treated coal was collected, weighed and analyzed.

The complete analyses of the five coals are shown in Appendix 1 (p.26). The significant results shown in TABLE 5 are that the relative amount of sulfur removed from each of the five ohio coals was equal to or more than the amount of sulfur removed from the reference coal (Ohio No.6, PSOC 1518). The amount of sulfur remaining in the five Ohio coals was from 0.96 to 1.17 per cent as compared to the values in the reference soal of 0.96 to 1.12 . From these results we can conclude that the use of e:hanol to remove sulfur from coal can be used in treating coals from ihe mejor coal seams in ohio.

\section{TABLE 5. SULFUR CONTENT OF FIVE OHIO COALB BEFORE AND AFTER TREATMENT}

\begin{tabular}{|c|c|c|c|}
\hline $\begin{array}{l}\text { SAMPLE ID. } \\
\text { Ruference } \\
\text { Coal-ohio } \\
\text { No. } 6 \\
\text { PSOC- } 1518\end{array}$ & $\begin{array}{c}\% \text { SULFUR } \\
\text { IN RAW } \\
\text { COAL } \\
3.6\end{array}$ & $\begin{array}{c}\text { \% SULFUR } \\
\text { IN TREATED } \\
\text { COAL } \\
1.12 \\
.75\end{array}$ & $\begin{array}{l}\text { AUTOCLAVE } \\
\text { TEMP. }{ }^{\circ} \mathrm{C} . \\
\\
320 \\
450\end{array}$ \\
\hline TASK II & SAMPLES & & \\
\hline No. $4 \mathrm{~A}$ & 3.37 & 1.17 & 320 \\
\hline No. 6 & 2.66 & 1.12 & 320 \\
\hline No. 8 & 3.84 & $\begin{array}{r}1.19 \\
.96\end{array}$ & $\begin{array}{l}320 \\
420\end{array}$ \\
\hline No. 9 & 3.16 & 1.16 & 320 \\
\hline No. 11 & 3.77 & 1.13 & 320 \\
\hline
\end{tabular}

In most samples there was some reduction in the Btu value of the treated coal as compared to the raw coal. This was probably due to the loss in volatiles in the coals as a result of the long heating periods in the autoclave. The results of the Btu measurements are not considered significant because of the small samples of treated coal available and because in larger scale continuous reactors the coal would not be subjected to high temperatures for long periods of time. All of the Btu analyses were run at the Modern Chemical Laboratory in Pomeroy, Ohio because our calorimeter was not in operation.

Ash, sulfur and moisture were also determined at the Modern Chemical Laboratory as a check against the analyses run in the laboratory at ohio University. Excellent checks were obtained in most of the sulfur values. Variations can be attributed to the small sample sizes and/or coarse particles in a sample. 
Waste Disposal.

Waste disposal or other environmental issues are not a major concern in the potential commercial operation of the ethanol process to remove sulfur from coal. There are little or no liquid or solid waste materials that would require a sludge pond, incineration or other waste disposal methods. Waste water treatment would be needed only to treat condenser or scrubber water which had been contaminated from a leak in the piping or equipment.

Sulfur dioxide $\left(\mathrm{SO}_{2}\right)$ formed during the regeneration of the copper reactor could be converted directly to sulfuric acid in a contact acid plant. Any gaseous hydrogen sulfide which is formed as a by-product could be recovered and used with essentially zero emission problems. It can be collected and sold as a gas although there is only a limited market for $\mathrm{H}_{2} \mathrm{~S}$ gas. The $\mathrm{H}_{2} \mathrm{~S}$ can be burned in a contact acid plant to make concentrated sulfuric acid which has broad industrial use, especially in making some types of fertilizers. By using the claus process, the $\mathrm{H}_{2} \mathrm{~S}$ can be converted to elemental sulfur with zero emission problems. The claus process (a catalytic oxidation process) is used on a large scale in petroleum refineries. The product sulfur is a solid which can be stored or shipped in conventional facilities. sulfur is used as such for agriculture purposes or as the conventional raw material for the production of sulfuric acid.

Any by-product acetaldehyde from the process is a lowboiling $\left(20^{\circ} \mathrm{C}\right)$ liquid which could be condensed and sold. It is used as an intermediate feed stock for the production of acetic acid, acetic anhydride, 2-ethyl hexanol, pentaerythritol, peracetic acid, paraldehyde and other chemicals. One potential market which might develop if cheap acetic acid were available is the production of calcium magnesium acetate (CMA) to be using as a non-corrosive highway and bridge de-icing agent.

\section{Changes in Program}

The initial work on the project was based on attempting to scale up a one-step process described in U.S. Patent 4,888,029 to use ethanol to remove sulfur from coal. Although some early results were very good, they could not be duplicated in later work and it was concluded that the process as described in the Shiley patent (U.S. patent $4,888,029$ ) could not be operated at larger scales even in the laboratory. No adequate explanation has been found for the inability to duplicate the early results in our laboratory autoclave.

An important breakthrough resulted from our development of a new laboratory process using copper as a combined catalyst and scavenger for the use of ethanol to remove sulfur from coal.

Documentation for the executive report is included in the full report. 


\section{MARRETING/CONGERCIALIZATION DIBCU8BION}

\section{Market Potential}

The economic merit of $90 \%$ removal of sulfur from coal is that the product from most coals would meet the EPA requirement of not more than 1.2 pounds of $\mathrm{SO}_{2}$ per million Btu of fuel burned. This would permit the continued operation of smaller or older boilers wj.thout the installation of expensive wet scrubbers. Installation space, capital and operating costs, and waste sludge disposal costs all would be eliminated. There are several potential markets for the product coal:

- direct delivery of the dry, pulverized low-sulfur coal to a power plant, possibly by an over-the-fence operation.

- shipment of dry pulverized coal, a coal slurry or coal briquettes from a central processing plant located at a mine.

- conversion to a lower ash coal slurry by oil agglomeration.

Until we know the results from larger scale experiments, it is not possible to estimate potential tonnages.

\section{Comparison with competing technologies}

There are many review articles in the literature on the chemical cleaning of coal. CHEMICAL ENGINEERING [1] presented a table which listed 13 different methods at various stages of development. Tsai [2] described the reactions of organic sulfur compounds, such as those found in coal, with acids and bases and described several proprietary methods such as the KVB process and the GE microwave process. Even the more recent review articles have not included the ethanol process.

Although several chemical processes for the removal of sulfur from coal have been proposed and some have developed through the pilot plant scale, none has been put into commercial production. These processes have ranged from solvent refined coal to microbial desulfurization, including the TRW gravimelt process, the Battelle Hydrothermal process, the Kennecott Copper Ledgemont process, the IGT Hydrodesulfurization process, the Hazen iron pentacarbonyl process, the Atlantic Research microbial removal of organic sulfur from coal, the General Electric microwave process and others. Among the problems associated with these different processes have been loss of heating value of the coal, corrosive reaction conditions, long reaction times, high temperatures and pressures, waste disposal problems and the inability to market the treated coal. [3].'

[1]Berry, R.I.,"Guide to Coal-cleaning Methods", Chemical
Engineering,Jan.,pp.47-49 (1981).
[2]Tsai, s.C.,"Fundamentals of Coal Beneficiation and
Utilization",Coal Science and Technology 2, Elsevier, New York,
pp 259 and 362-4 (1982).
[3]Merritt, P.C., "Advanced Coal Cleaning Processes Sought for
Superclean Coal",Coal Age, June,pp.94-101 (1986).


The potential importance of the proposed research in providing practical solutions to the problems affecting the use of ohio coal is very great. Most other proposed processes for the removal of sulfur from coal, regardless of the cost, have been limited in their technical success in removing organic sulfur from coal. Several are able to remove the pyritic sulfur, others can remove pyritic sulfur and part of the organic sulfur but very few can remove both the pyritic and organic sulfur. Those that can remove both have been based on the use of acids, bases or salts at high temperature and corrosive conditions, long reaction times, serious waste disposal problems for the by-products from the reaction and/or loss of heating value of the coal. Successful development of the process to use ethanol for the removal of sulfur from coal would overcome the disadvantages of previous processes.

The economic and commercial feasibility of any process which may eventually result from this research will depend in part on the enforcement of the recent acid rain legislation, the ability of utilities and industry to switch to alternate supplies of low sulfur coal, the price and uninterrupted supply of natural gas or fuel oil, and the speed with which the process can be developed. Even if the process cannot be put into commercial production in time to avoid a significant further reduction in the use of high-sulfur ohio coal, there will be continuing efforts to use our plentiful coal reserves in an environmentally acceptable manner. This can best be done by removing the sulfur from the coal before combustion but it must be realized and accepted that there will be a significant increase in the cost of producing clean coal.

Cost of clean coal per million Btu should be compared to the cost of fuel oil, to the cost of high sulfur coal plus the capital and operating cost of a scrubber, or to the cost of low-sulfur coal plus shipping costs to deliver it to the ohio valley users rather than to compare it with the present delivered cost of non-compliance coals.

\section{Next steps}

The project is being continued with funding from other sources. The technical work will consist of developing the process on a laboratory scale and scaling up the operation to one to ten pound batches to get design and operating data for a pilot plant. steps to commercialization will require the construction and operation of a demonstration plant to operate at 10 tons per hour followed by a commercial plant to operate at 100 or more tons per hour. 


\section{REFERENCES}

1. M.D. Stephenson, M. Rostam-Abadi, L.A. Johnson and C.W. Kruse, in: Processing and Utilization of High Sulfur Coals, Ed.: Y.A. Attia, Elsevier, 1985, p. 353.

2. J.D., Batchelor, E. Grin and C.W. Zielke, Ind. Eng. Chem., 1960, 52 (2) 161 .

3. A. Attar, Fuel, 1978, 57, 201.

4. A.L. Yergey et.al., Ind. Eng. Chem., Proc. Des. Develop., 1974, 13, (3) 233

5. L.Robinson, Fuel, 1976, 55, 193.

6. A.B. Tipton, in: Coal Desulfurization, Ed. : T.D. Wheelock, (ACS Symposium Series 64), 1977, p. 280.

7. N.S. Boodman, T.F. Johnson and K.C. Krupinski in: Coal Desulfurization, Ed.: T.D. Wheelock, (ACS Symposium Series 64), 1977 , p. 248

8. A.B. Tipton, in: Coal Processing Technology, AIChE, 1981, Vol. 7, p. 94 .

9. A.K. Burnham, N. Kirkman Bey and G.J. Koskinas, in: Oil Shale, Tar Sands and Related materials, Ed.: H.C. Stauffer, (ACS symposium Series 163), 1981, p. 61 .

10. S.S. Block, J.B. Sharp and L.J. Darlage, Fuel, 1975, 54, 113.

11. E. Gorin, G.P. Curran and J.D. Batchelor, US Patent 2824047 (February 18, 1958).

12. A.M. Squires, Int. J. Sulfur Chem., 1972, 7B, (1), 85 .

13. Ph. R. Westmoreland and D.P. Harrison, Environmental Science \& Technology, 1976, 10, (7) 659 .

14. S.J. Stinnett, D.P. Harrison and R.W. Pike, Environmental Science \& Technology, 1974, $8,(5), 441$.

15. P.G. Wapner and C.M. Lee, In" Processing and Utilization of High Sulfur Coals II, (Eds.: Y.P. Chung and R.D. Caudle), Elsevier, 1987 , p. 371 .

16. P. Sabatier, Catalysis in organic Chemistry, Part II of: Catalysis then and now, (by P.H. Emmet and P. Sabatier), Franklin publishing Company, Inc., 1965.

17. O. Weisser and S. Landa, Sulphide Catalysis, Their Properties and Applications, Pergamon Press and Friedr. Vieweg \& Son, 1973.

18. R.L. Warren, et.al., in: Proceeding and Utilization of High Sulfur Coals II, (Eds.: Y.P. Chung and R.D. Caudle), Elsevier, 1987, p. 235 .

19. A.K. Biswas and W.G. Davenport, Extractive Metallurgy of Copper, Sec. edition, Pergamon Press, 1980.

20. C.L. Thomas, Catalytic processes and proven catalysts, Acad. Press, 1970 .

21. R.H. Shiley, et.al., U.S. Patent 4888029 , December 19, 1989.

22. D.K.Fleming, R.D.Smith and M.R,X.Aquuino in: Coal

Desulfurization, Ed: T.D. Wheelock, (ACS Symposium series 64), 1977, p267. 


\section{APPENDIX I}

COMPLETE ANALYSES OF FIVE OHIO CORLS

SAMPLE CHIO CORL DATE STATUS
Ident if $i-$ NUMBER

Btw/1t. \% ASH

cation

Chemical Chemical

BHIO U. Modern OHIO U. OHIO U. CARBON OHIO U. Modern

RuITOCLAU

Lab. Lab. Analyzer Lab. Analyzer Analyzer Analyzer Analyzer Lab.

AEG. $C$.

Reference

PSOC-1518

Penn. Stat

$\begin{array}{llc}6 & 4 / 23 / 91 & \text { RAW } \\ 6 & 2 / 14 / 92 & \text { RRI } \\ 6 & 6 / 28 / 91 & \text { TREATED } \\ 6 & 8 / 7 / 91 & \end{array}$

$13,678 \quad 10.44$

$12,470 \quad 9.56$

Lab.

$3.67 \quad 3.6$

$10,469 \quad 8.29$

IASK II

4 10 $10 / 24 / 91$ RAW

$11,127 \quad 20.09$

SAMPLE

$\begin{array}{ll}10 / 24 / 91 & \text { RAW } \\ 10 / 25 / 91 & \text { TREATED }\end{array}$

$11,602 \quad 17.14$

19.6

1.12

36.26

D3.8

.99

3.97

.75

1.81

6.2

450

$\begin{array}{ccc}3.93 & 3.37 \\ .91 & 1.17\end{array}$

35.06

454.08

2.73

3.13

2. 92

320

$\begin{array}{lllccc}" 1 & 6 & 10 / 30 / 91 & \text { RRW } & 13,340 & 5.37 \\ 1 & 6 & 10 / 31 / 91 & \text { TREATED } & 10,643 & 15.8\end{array}$

$\begin{array}{lll}5.32 & 2.39 & 2.66\end{array}$

39.256 .48

4.92

4.75

$\equiv 20$

" $\quad 8$

$10 / 22 / 91$ RAW

$12,281 \quad 11.72$

$10 / 23 / 91$ TREATED $12,37916.07$

$11 / 06 / 91$ TREATED 10,369 16.8

11.69

3.74

1.12

35.37

52.94

2. 13

1.79

3.55
2.57

320
420

a

$\begin{array}{ll}11 & 9 \\ 1 & 9 \\ & \end{array}$

$10 / 20 / 91$ RAW

$12,748 \quad 11.31$

10/29/91 TREATED

11.31

1.01
.8

.96

$36.08 \quad 52.65$

2.68

2.55

$\begin{array}{ll}2.69 & 3.16 \\ .85 & 1.16\end{array}$

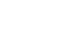

.

2.29

3.3

$\$ 20$

$13.02 \quad 2.7 \quad 3.77$

$33.5 \quad 53.48$

2.29

2.32

$\$ 20$

* Low values probably due to small sample size and/or coarse particles. 
APPENDIX II

TABULATION OF REBULTS OF ALL EXPERIMENTS DURING OCDO CO-8PONBORBHIP 
$9 / 21 / 92$

RUNA

NUMBER

$10 E$

107

108

109

110

111

112

113

114

115

116

$11 ?$

118

119

120

121

122

123

124

125

126

127

128

129

130

131

132

133

134

135

136

137

138

139

140

141
FLL FUNS TO 2/25,93

FIPPFIRENT REMOUEO $\%$ SO

$\begin{array}{ccc}10 / 1 / 91 & 17.9 & 3.06\end{array}$

$10,3,91$

$10 / 11 / 91$

$$
69.2
$$

1.15

$\begin{array}{ccc}10 / 15 / 91 & 59.8 & 1.5 \\ 10,17 / 91 & 33 & 2.5\end{array}$

$\begin{array}{lll}10-21-91 & 76.4 \quad .88\end{array}$

$10-23-91$

6.7.?

1.19

$10-25-91$

$10-29-91$

65.3

1.17

63.3

1.16

$10 / 31 / 91$

57.

1.12

$11 / 4 / 91$

1. 691

$11,15,91$

$11 / 20 / 91$

$11 / 26,91$

$12 / 3 / 91$

$12 / 5 / 91$

$12 / 9,91$

$12 / 13 / 91$

$12 / 18,91$

$12 / 23,91$

70

1.13

.961

$54 \quad 1.69$

$18.8 \quad 3.45$

$18.8 \quad 3.45$

$11.6 \quad 3.82$

$18.6 \quad 3.45$

$19.6 \quad 3.43$

$1.2 \quad 3.23$

$5.14 \quad 3.32$

6. $3 \quad 3.28$

$\begin{array}{lcl}1 / 15,92 & 17 & 3.53 \\ 1 / 20,92 & 13 & 3.68 \\ 1 / 2,92 & 12.7 & 3.64 \\ 2 / 11 / 92 & 26.4 & 3.06 \\ 2 / 6,92 & 27.6 & 3.27 \\ 2 / 10,92 & 29.9 & 2.74 \\ 2 / 12 / 92 & 32.4 & 2.63 \\ 2 / 1792 & 39.4 & 2.19 \\ 2 / 19,92 & 32 & 2.45 \\ 2,24,92 & 30.4 & 2.98 \\ 2,29 / 92 & 32.7 & 2.94 \\ 3,3,92 & 24.6 & 2.99 \\ 3 / 4,92 & 19 & 2.95 \\ 3,5,92 & 28 & 2.67 \\ 3,9,92 & 31.9 & 2.45\end{array}$

45.9

\section{7}

53.3

46.7

43.5

40

39.1

37.1

42.8

46.3
TABULATION OF ETHANOL RUNS IN RUTOCLRUE FT OHIO UNIUERSITY

$\approx S$ IN COAL MESH AH COAL OHIO \#E SIZE

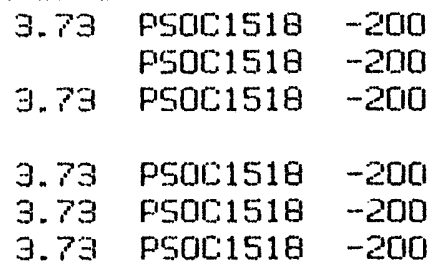

3.97

NO. 8

-200
-200

3.16

$-200$

2.66 OHIO NO.6 -200

$\begin{array}{lll}3.77 & \text { No.11 } & -200 \\ 3.59 & \text { No. } 9 & -200\end{array}$

3.68 No. $\mathrm{B} \quad-200$

4.25 PSOC151日 -200

4.25 PSOC151日 -200

4.6 PSOC1518 -200

4.24 PSOC1518 - 200

4.27 PSOC1518 -200

3.27 P50C1518 -200

3. 5 P5001518 -200

3.5 PSOC1518 -200

4.27 P50C:1519 -200

4.29 FSOC1518 -200

4.16 FISDC $1518-200$

4.38 PSOL1518 -100

3.79 PSTIL1519 -100

3.89 PSOC $1518-100$

3.89 PSOI:1518 -100

3.6 PSOC $1519 \quad-100$

3.E ILL NO.6 -100

4.29 ILL NO. -100

4.35 ILL NOI.6 -100

3.64 pS001516 -100

3.64 PSOC1518 -100

3.74 FSOC $1518-100$

3.6 P5001519 -100
ACT IUATOR

MONE

$1.5 \% 02$

1. $5 \%$ 02

NONE

$1.5 \% 02$

$1.5 \% 02$

$1.5 \% 02$

$1.5 \% 02$

$1.5 \% 02$

$1.5 \% 02$

1. $5 \% 02$

$1.5 \% 02$

$1.5 \% 02$

$1.5 \% 02$

$1.5 \% 02$

NONE

$0.5 \% \mathrm{NO}$

0. $5 \% \mathrm{NO}$

$0.5 \% \mathrm{NO}$

1. $5 \% 02$

$0.5 \% \mathrm{NO}$

$0.5 \% \mathrm{NO}$

$0.5 \%$ NO

$0.52 \% \mathrm{NO}$

$0.52 \% \mathrm{ND}$

$0.52 \% \mathrm{NO}$

$0.52 \% \mathrm{ND}$

D. $52 \% \mathrm{NO}$

0. $52 \% \mathrm{ND}$

$0.52 \% \mathrm{NO}$ NONE
$0.5 \% 10$
NONNE
NONE

$0.52 \% \mathrm{NO}$

$\begin{array}{cc}\text { CARRIER } & \text { RATE } \\ \text { GAS } & \text { ml/min } \\ \text { N2 } & 30 \\ \text { N2 } & 30 \\ \text { M2 } & 30\end{array}$

TEMF

C.

420

420

320

420

420

320

325

320

320

320

420

425

420

425

320

420

420

420

410

430

320

320

320

420

420

420

420

420

420

420

420

420

420

420 420 
PRESS III EXCESS ETHFNOL.

$\begin{array}{cccc}\text { Psig } & \text { ETOH ETOH } & \text { RATE } \\ 50 & 8.8 & 13 & 2.5 m 1 / m\end{array}$

$\begin{array}{llll}50 & 8.8 & 13 & 2.5 \mathrm{ml} / \mathrm{m} \\ 50 & 0 & 0 & 0 \\ 50 & 8.7 & 13 & 2.5 \mathrm{ml} / \mathrm{m}\end{array}$

$\begin{array}{llll}50 & 0.8 & 13 & 2.5 \mathrm{ml} / \mathrm{m} \\ 50 & 8.7 & 13 & 2.5 \mathrm{ml} / \mathrm{m} \\ 50 & 8.7 & 13 & 2.5 \mathrm{ml} / \mathrm{m}\end{array}$

$50 \quad 8.8 \quad 13 \quad 2.5 \mathrm{ml} / \mathrm{m}$

$\begin{array}{llll}50 & 8.7 & 14 & 2.5 \mathrm{~m} 1 / \pi \\ 50 & 8.7 & 15 & 2.5 \mathrm{~m} 1 / \pi\end{array}$

$\begin{array}{llll}50 & 8.9 & 18 & 2.5 \mathrm{~m} 1 / \mathrm{m} \\ 50 & 8.9 & 13 & 2.5 \mathrm{~m} 1 / \mathrm{m} \\ 50 & 8.7 & 13 & 2.5 \mathrm{~m} 1 / \mathrm{m}\end{array}$

$50 \quad 8.6 \quad 13 \quad 2.5 \mathrm{~m} 1 / \mathrm{m}$

$\begin{array}{cccc}50 & 10 & 13 & 2.5 \mathrm{ml} / \mathrm{m} \\ 50 & 6.5 & 9 & 2.5 \mathrm{ml} / \mathrm{m}\end{array}$

$\begin{array}{llll}50 & 9.2 & 11 & 2.5 \mathrm{ml} / \mathrm{m}\end{array}$

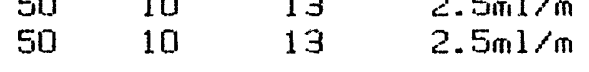

$\begin{array}{llll}50 & 10 & 17 & 2.5 \mathrm{~m} 1 / \mathrm{m}\end{array}$

$\begin{array}{llll}50 & 10 & 16 & 2.5 \mathrm{~m} 1 / \mathrm{m} \\ 50 & 11 . & 17 & 2.5 \mathrm{~m} 1 / \mathrm{m}\end{array}$

$\begin{array}{llll}50 & 6 & 8 & 2.5 m 1 / m \\ 50 & 6 & 8 & 2.5 \mathrm{ML} / \mathrm{M}\end{array}$

$\begin{array}{llll}50 & 6 & 8 & 2.5 M L / M \\ 50 & 6 & 8 & 2.5 M L / M\end{array}$

$50 \quad 6 \quad 8 \quad$ 2. SML $/ M$

2. $\mathrm{GML} / \mathrm{M}$
$2.5 \mathrm{HL} / \mathrm{M}$

1. OMNL/NA

0. 5 H 1 L/M

$1+P L / M$
$0.5 P L A M$

NONE:

NONE

$1 \mathrm{FH} / \mathrm{WH}$

\begin{tabular}{|c|c|c|c|c|}
\hline \multicolumn{2}{|c|}{ HOURS IN WEIGHT } & \multirow{2}{*}{$\begin{array}{c}\text { GMS. COFL } \\
\text { RECOUVESY } \\
8.8\end{array}$} & $\begin{array}{l}\text { SAMPLEE } \\
\text { HOLOER }\end{array}$ & \multirow[t]{2}{*}{$\begin{array}{l}\text { BEFAD } \\
\text { ELAST }\end{array}$} \\
\hline 6.5 & $\begin{array}{l}10 \\
0\end{array}$ & & $(* 14)$ & \\
\hline 6.5 & 10 & 9.24 & $(* 13)$ & \\
\hline $\begin{array}{l}5.5 \\
5.5\end{array}$ & $\begin{array}{l}10.1 \\
10.1\end{array}$ & $\begin{array}{l}9.36 \\
9.23\end{array}$ & $\begin{array}{l}(* 13) \\
(\neq 13)\end{array}$ & \\
\hline 5.5 & 10.1 & 9.14 & $(* 2)$ & \\
\hline $\begin{array}{l}5.5 \\
5.5\end{array}$ & 10 & 9.05 & (*2) $q$ & \\
\hline 6.5 & 9.96 & 8.96 & $(* 2)$ & YES \\
\hline 6 & 10 & 8. $5 \varepsilon_{1}$ & $(* 2)$ & \\
\hline 6 & 10 & 9.41 & $(* 2)$ & \\
\hline 5.5 & 10 & 8.32 & $(\approx 2)$ & \\
\hline 5 & 10 & 7.51 & $(* 15)$ & \\
\hline 6 & 10 & 7.51 & $(* 15)$ & \\
\hline 6 & 10 & 7.75 & $(* 15)$ & \\
\hline 6 & 10 & 9.09 & $(* 15)$ & \\
\hline 6 & 10 & 7.85 & $(* 15)$ & \\
\hline E & 10 & 7.83 & $(* 15)$ & \\
\hline 5.5 & 10 & 6.82 & $(* 15)$ & \\
\hline & 10 & 7.73 & $(* 15)$ & \\
\hline 5.5 & 10 & 8.77 & $(* 15)$ & YE \\
\hline 6 & 10 & 8.7 & $\langle * 1)$ & \\
\hline 6.5 & 10 & 8.46 & $(* 1)$ & \\
\hline 6 & 10 & 8.7 & $(* a)$ & \\
\hline 7 & 10 & 7.37 & $(* 2)$ & \\
\hline 7 & 10 & & $\left(*_{2}\right)$ & \\
\hline 5 & 10 & 7.06 & $(\approx 2)$ & Ye \\
\hline 5.5 & 10 & a. 07 & $(\approx 2)$ & \\
\hline 5.5 & 10 & 7.77 & $(* 2)$ & YE \\
\hline 8.5 & 60 & 47 & $(* 2)$ & \\
\hline 11 & 20 & 17. & $(* 2)$ & \\
\hline 8 & 20 & 17. & $(* 2)$ & \\
\hline 3.5 & 10 & 7.76 & $(* 2)$ & \\
\hline 4 & 10 & 7.76 & $(* 13)$ & \\
\hline 4 & 10 & 8.07 & $(* 13)$ & \\
\hline 4 & 10 & 7.6 & $(* 2)$ & \\
\hline
\end{tabular}

SAMPLE

BLAST NUMEER

DPEERTOR

$(* 5)$ BLANK

$(* 5)$ STAIT

$(* 5)$
$(\neq 5)$
$(* 5)$

$(* 5)$

$(* 5)$

$(* 5)$

$(* 5)$

(*5) GL.ASS

$(* 6)$ REPE

$(* 16)$ REPE

$(* 16)$ NEW

(*16) AUDTCL

$(* 16)$ REPEF

(*16) CHECK

(*16) CHECK

$(* 17)$ NEW

$(* 17)(* 2)$

$(* 17)(* 2)$

$(* 17)(* 2)$

$(* 17)$ CHECK
$(* 17)$ NEL
$(* 17)$ ELANK

(*17) STEEL

(*17) NG A
(*14)

(*13)

$(* 13)$

$(* 13)$

$(* 2)$ ?

$(* 2)$

$(* 2)$

$(* 2)$

$(* 15)$
$(\neq 15)$
$(* 15)$

$(\because 15)$

$(* 15)$

$(* 15)$

$(* 15)$

$(* 1)$
$(* 1)$
$(* 2)$

$(* 2)$

$(* 2)$

(*2)

$(* 2)$

$(* 2)$

$(* 13)$

$(* 13)$
YES

YES

$?$

YES

YES
YES
YES

NO

NO

NO

NO

YES

YES

NO

NES

YES

NO
YES
$Y E S$

NO

YES

MO

YES
NO
NO
NOTES (*)

BLFNK - NO ACTIUATOR

STATRTED - ETHANGL. PUMP FAILURE

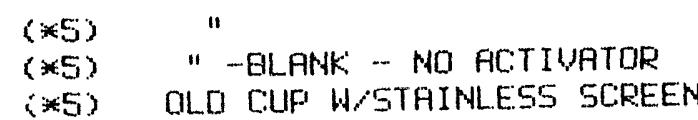

(*5) FIUE OHIO COFLS

$(* 5)$

(*5) FIVE OHIO COALS

(*5) Na. B at hugher temp.

(*5) GLASS CUP, FILTER, TUBING AND GEFKER

(*6) REPEAT W/ NO.6- PSOC: 1518

REPEFT FUIN

(*1E) REFEETT EIUN AT 3201 C.

(*16) MEW TFINK, OF $0.5 \%$ NO IN NI TROIGEN

(*1E) RUOTCLAUE CHFEGED $12 / 4 / 91$, RUN MFDE $12 / 13 / 91$

(*16) REPEET OF $12 / 13 / 91$
$(* 16)$ CHECK ON EOUIPMENT W $1.5 \%$ CI2 - NO REMOUFL

(*16) CHECK ON EQUIPMENT

*16) CHELR ON EQUIPMET

*17) NEW BAG PSOC1518. NEW TFNK HE + 0.52\% NO, FNAFLYZE

*17) (*2) COPPEWR CUIF WITH NEW 55 SCREEN

$(* 17)(* 2)$ COPPER CUP WITH SS SCREEN + COPPER SCREEN

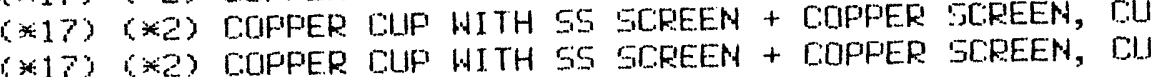

(*17) CHECK VALUE REPLACED

(*17) RE.W LHECK VALLUE

$(* 17)$ BLANK. RIN

(*17) STEEL CLUP WI

(*17) COPPER CIJF' +55 SCREEN + COFPER GCREEN 


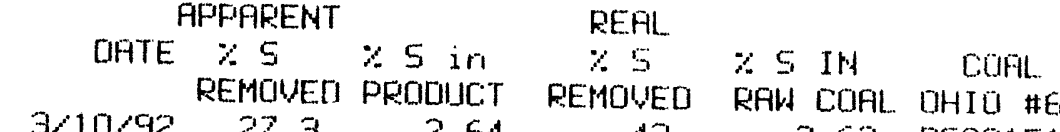
$\begin{array}{ll}3 / 10 / 92 & 27 . \\ 3 / 12 / 92 & 35 . \\ 3 / 16 / 92 & 38.5\end{array}$ $\begin{array}{lll}54.4 & 3.64 & \text { PSOC15 }\end{array}$ $\begin{array}{cccccc}3 / 18 / 92 & 39 & 2.24 & 53.3 & 3.62 & \text { P SOC1518 } \\ 3 / 20 / 92 & 36.7 & 2.29 & 48.9 & 3.62 & \text { P SOC 1518 } \\ 3 / 24 / 92 & 32.8 & 2.44 & 48.2 & 3.63 & \text { F50C1518 }\end{array}$ $\begin{array}{cccccc}3 / 26 / 92 & 32 & 2.47 & 47.7 & 3.69 & \text { PSOC1519 } \\ 4 / 2 / 92 & 27.4 & 2.7 & 41.9 & 3.72 & \text { PSOC } 1518\end{array}$ $\begin{array}{llllll}4 / 8 / 92 & 34.5 & 2.39 & 52.2 & 3.66 & \text { PSOC1518 } \\ 4 / 10 / 92 & 40.3 & 2.11 & 54.7 & 3.65 & \text { PSOC1519 } \\ 4 / 14 / 92 & 31.9 & 2.48 & 47.5 & 3.64 & \text { PSOC1518 }\end{array}$ $\begin{array}{lll}4 / 20 / 92 & 29.5 & 2.94 \\ 4 / 22,92 & 37.5 & 2.18 \\ 4 / 29,92 & 33.6 & 2.29\end{array}$ $\begin{array}{ll}5 / 14 / 92 & 12 . \\ 5 / 19 / 92 & 20.6 \\ 5 / 21 / 92 & 19.1\end{array}$

$\begin{array}{ll}5 / 17 / 92 & 33 \\ 5 / 19 / 92 & 29 \\ 6 / 3 / 92 & 35\end{array}$

$6 / 10 / 92 \quad 46.6$ $\begin{array}{ll}6 / 22,92 & 46.6 \\ 6 / 23,92 & 44.2\end{array}$ $\begin{array}{ll}6 / 25 / 92 & 47.6 \\ 7 / 1 / 92 & 47.5\end{array}$

$\begin{array}{ll}7 / 9 / 92 & 44.1 \\ 7 / 1392 & 44.6 \\ 7 / 15 / 92 & 37.7\end{array}$

$\begin{array}{ll}7 / 7992 & 94.1 \\ 720 / 92 & 45.1 \\ 72292 & 45.7\end{array}$

$\begin{array}{cc}7 / 29 / 92 & 43 \\ 724 / 92 & 43.3 \\ 7 / 29 / 92 & 36.8\end{array}$

3.64 PSOC151日

$\begin{array}{ll}\text { 4. } 17 & \text { ILL.NA. } 6 \\ \text { 3. } 49 & \text { PSOC1516 } \\ 3.45 & \text { PSOC151日 }\end{array}$

$\begin{array}{ll}4.28 & 111 . \text { No. } 5 \\ 4.28 & \text { I11. Ho. }\end{array}$

3. 57 PSOC1518

$\begin{array}{ll}\text { 3. } 48 & \text { P SOC } 1518 \\ \text { 3.47 } & \text { PSOC1518 }\end{array}$

3. 22 PSOC1518

3. 4 P PSOC151日

$\begin{array}{ll}51 & P 50 C 1518 \\ 56 & \text { P } 50 C 1518 \\ 49 & \text { P } 5001518\end{array}$

$\begin{array}{ll}3.59 & \text { PSOC1518 } \\ 3.54 & \text { PSOC1518 } \\ 3.37 & \text { P5OC1518 }\end{array}$

$\begin{array}{ll}1.96 & 57.9 \\ 2.1 & 53.7\end{array}$

$\begin{array}{ll}2.2 & 51 . \\ 1.65 & 59 \\ 1.69 & 59 .\end{array}$

1.92
1.91
2.13

3. 37 PSOC151日

3. 37 PSOC1518
ACTIUATOR CFRRIER RHTE TEMF

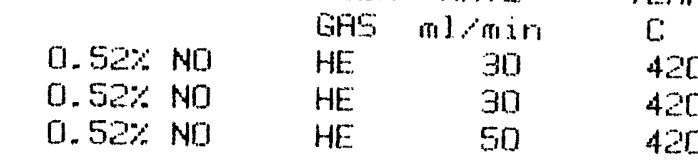

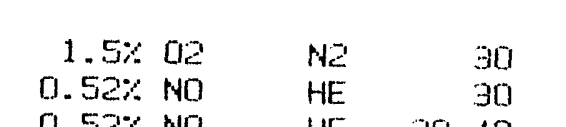

NONE
$0.52 \%$ NO
$0.5 \%$ NO

$0.52 \% \mathrm{NO}$
$0.52 \% \mathrm{NO}$
NGNE

$\begin{array}{ll}-100 & 0.52 \% \text { NO } \\ -100 & \text { NONE } \\ -100 & 0.5 \% \text { NO }\end{array}$

$20\left(\begin{array}{ccc}30 & 420 \\ 20 & 420-4 \\ 420 & 420\end{array}\right.$

$\begin{array}{ll}\mathrm{HE} & -450 \\ \mathrm{N2} & -180 \\ \mathrm{He} & 50 \%\end{array}$

$\begin{array}{rr}-80 & \text { NANE } \\ -80 & \text { NONE } \\ -80 & 0.5 \% \\ -80 & \text { NO }\end{array}$

$\begin{array}{ll}\mathrm{N} 2 & 30 \\ \mathrm{NZ} & 40 \\ \mathrm{He} & 70\end{array}$

$0.5 \%$ NO

He 60

100

$0.5 \% \mathrm{NO}$ He $601-20$
$0.5 \% \mathrm{NO}$ He 100
$0.5 \% \mathrm{NO}$ He

$0.5 \% \mathrm{NO}$

$\begin{array}{cc}\text { He } & 10-20 \\ \text { He } & 80 \\ \text { He } & 40-80\end{array}$

.

$\begin{array}{lr}\text { He } & 50 \\ \text { He } & 30-60 \\ \text { He } & 50-100\end{array}$

He $201-90$

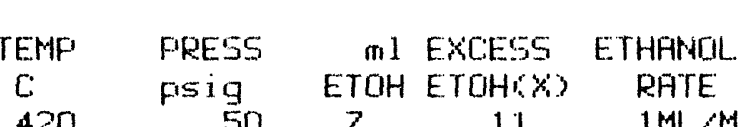

$\begin{array}{ccccc}420 & 50 & 7 & 11 & 1 \mathrm{ML} / \mathrm{M} \\ 420 & 100+ & 30 & 46 & 50 \mathrm{LL} / \mathrm{M}\end{array}$

$\begin{array}{ccccc}420 & 100 & 62 & 95 & 0.5 \mathrm{ML} / \mathrm{M} \\ 420 & 75 & 15 & 29 & 0.3 \mathrm{ML} / \mathrm{M} \\ 420 & 35 & 9 & 14 & 0.5 \mathrm{ML} / \mathrm{M}\end{array}$

420

420
485

$\begin{array}{ll}50 & 8 \\ 35 & 6 \\ 35 & 6\end{array}$

$12 \quad 1.5 \mathrm{ML} / \mathrm{M}$

420-490

35
$60-1-30$
35

420
420
435

385

440
420
380

$\begin{array}{cc}480 & 100 \\ 480 & 301-10\end{array}$

$\begin{array}{ll}45 & 6 \\ 48 & 10 \\ 60 & \end{array}$

19

a 1 MLAM

. RATra 1milimin

O. GMLLGM 1ml/mir

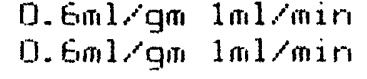

0.6ml /gm 1-2ml/min $\begin{array}{rl}11.0 m 1 / \mathrm{gm} & 0.5 \mathrm{~m} 1 / \mathrm{min} \\ 1.1 \mathrm{~m} 1 / \mathrm{gm} & 0.5 \mathrm{~m} 1 / \mathrm{min}\end{array}$

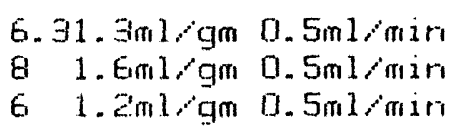

$480 \quad 100$ E $1.2 \mathrm{ml} / \mathrm{gm} 0.5 \mathrm{ml} / \mathrm{min}$

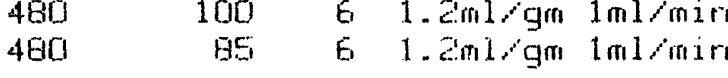

$465 \quad 90 \quad E_{6} 1.2 \mathrm{iml} / \mathrm{gm} 1 \mathrm{~m} 1 / \mathrm{min}$

$475 \quad 601-90 \quad 6 \quad 1.2 m 1 / g m$ 1mlimir

tan

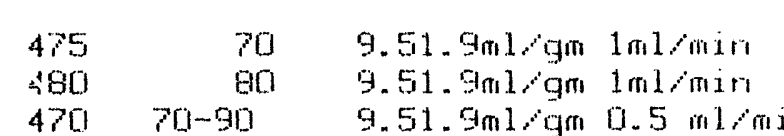

HOURS IN WEIEHT GIMS. CAFL SFMPLE

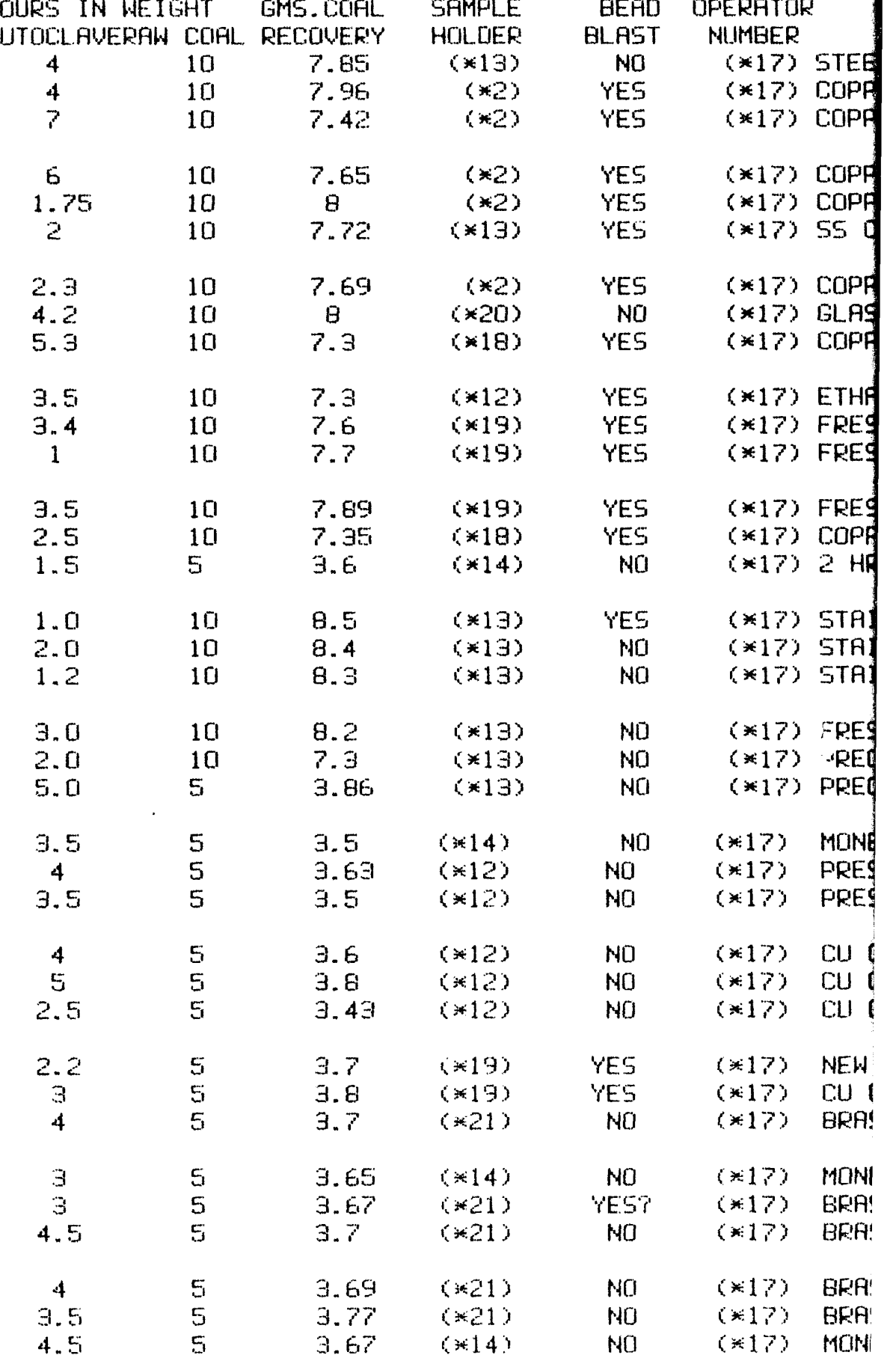




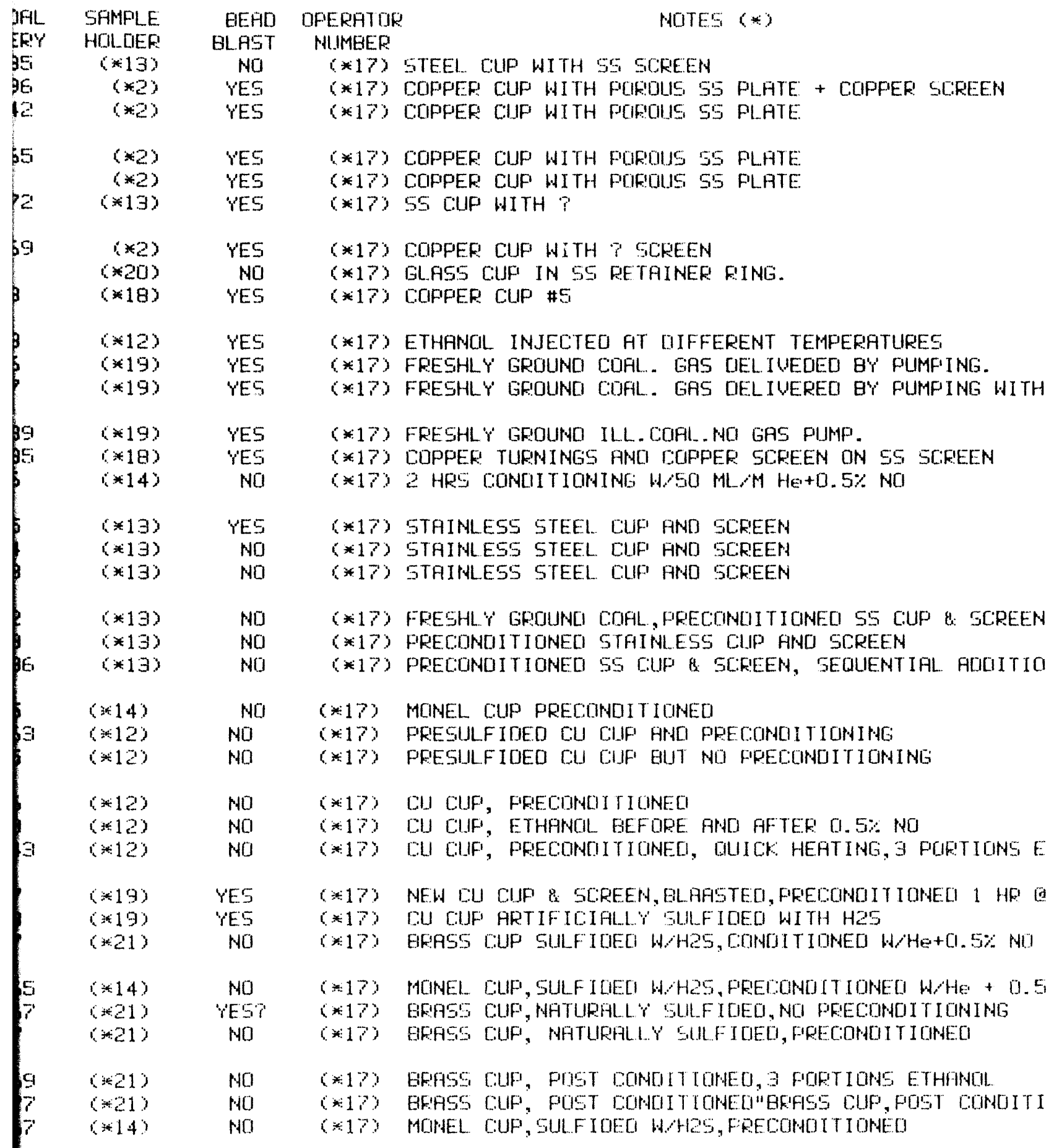




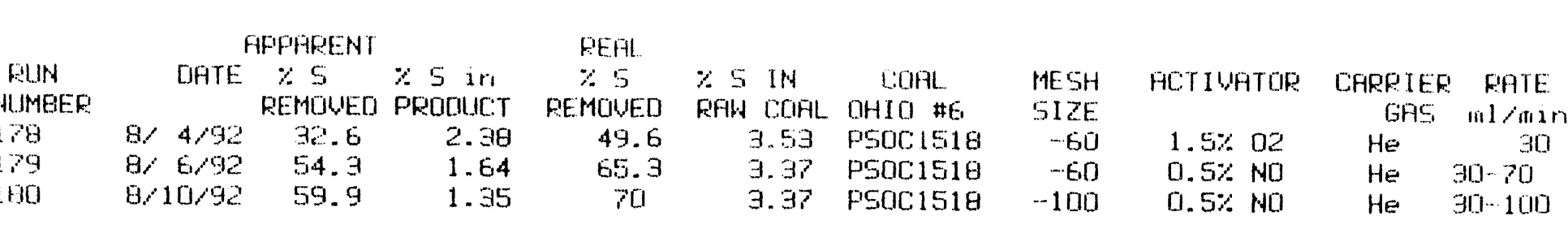

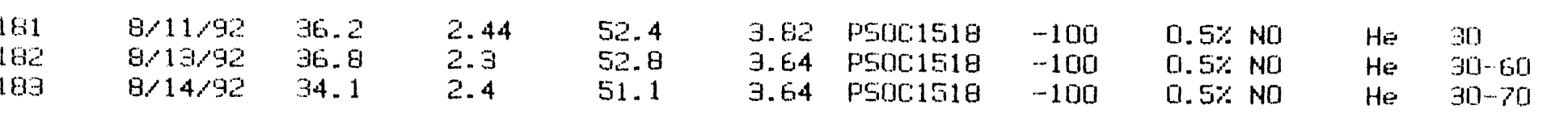

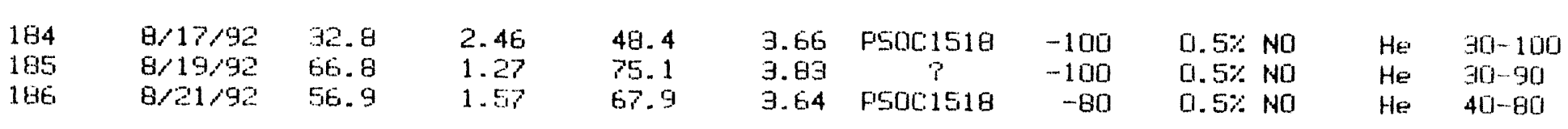

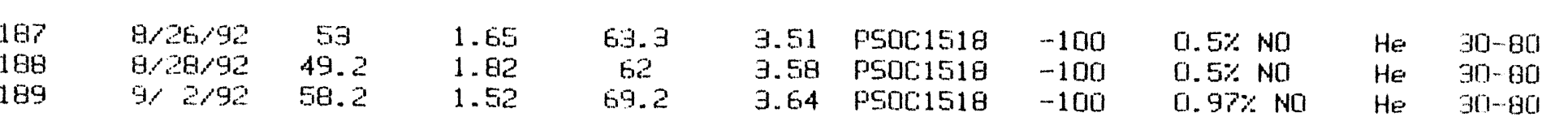

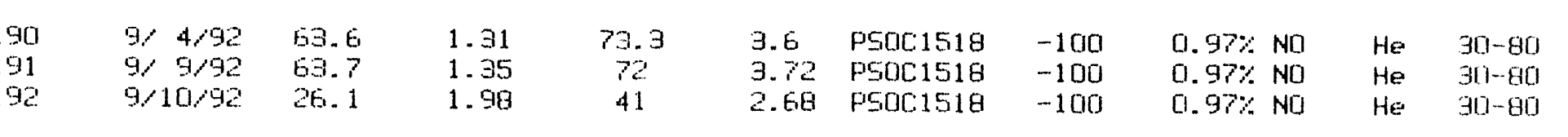

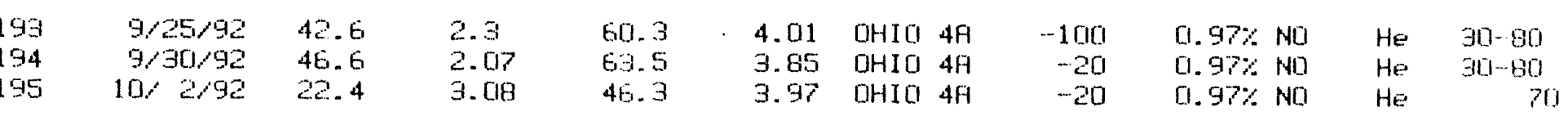

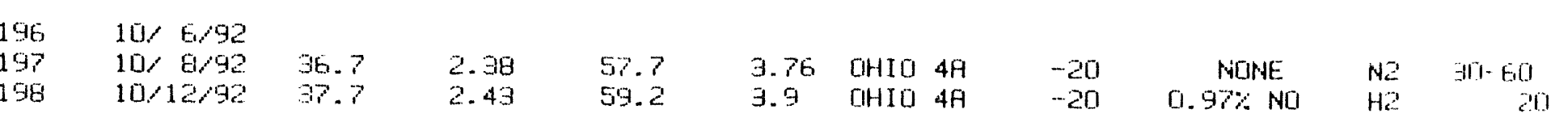

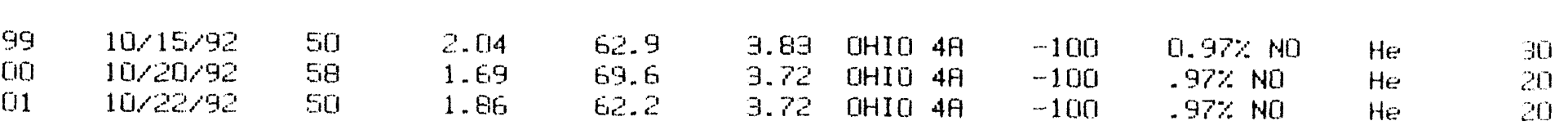

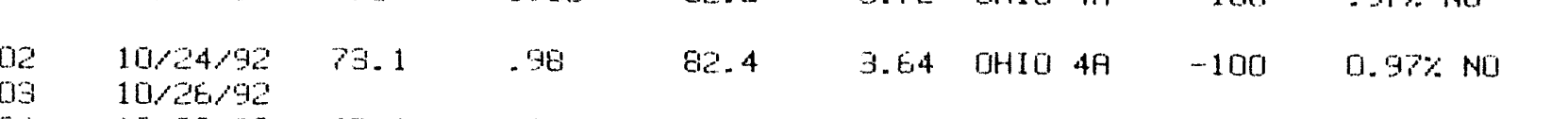

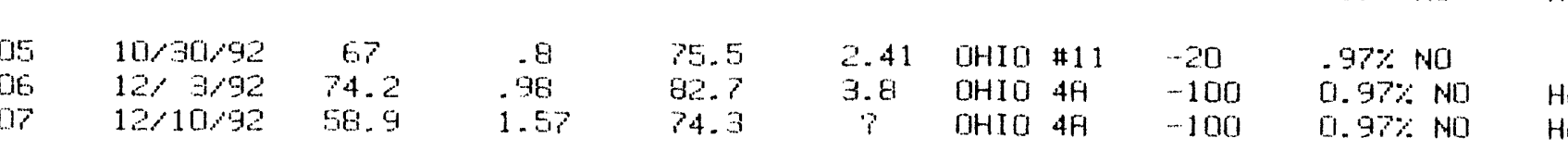

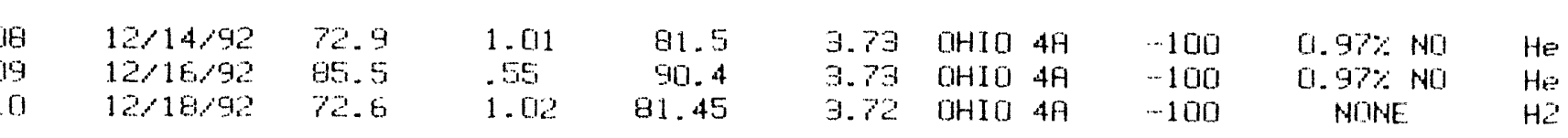

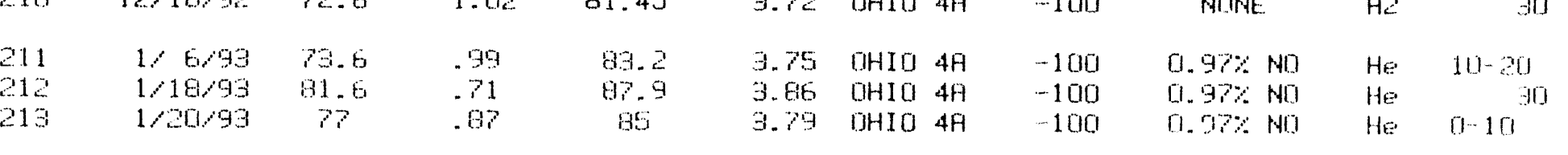

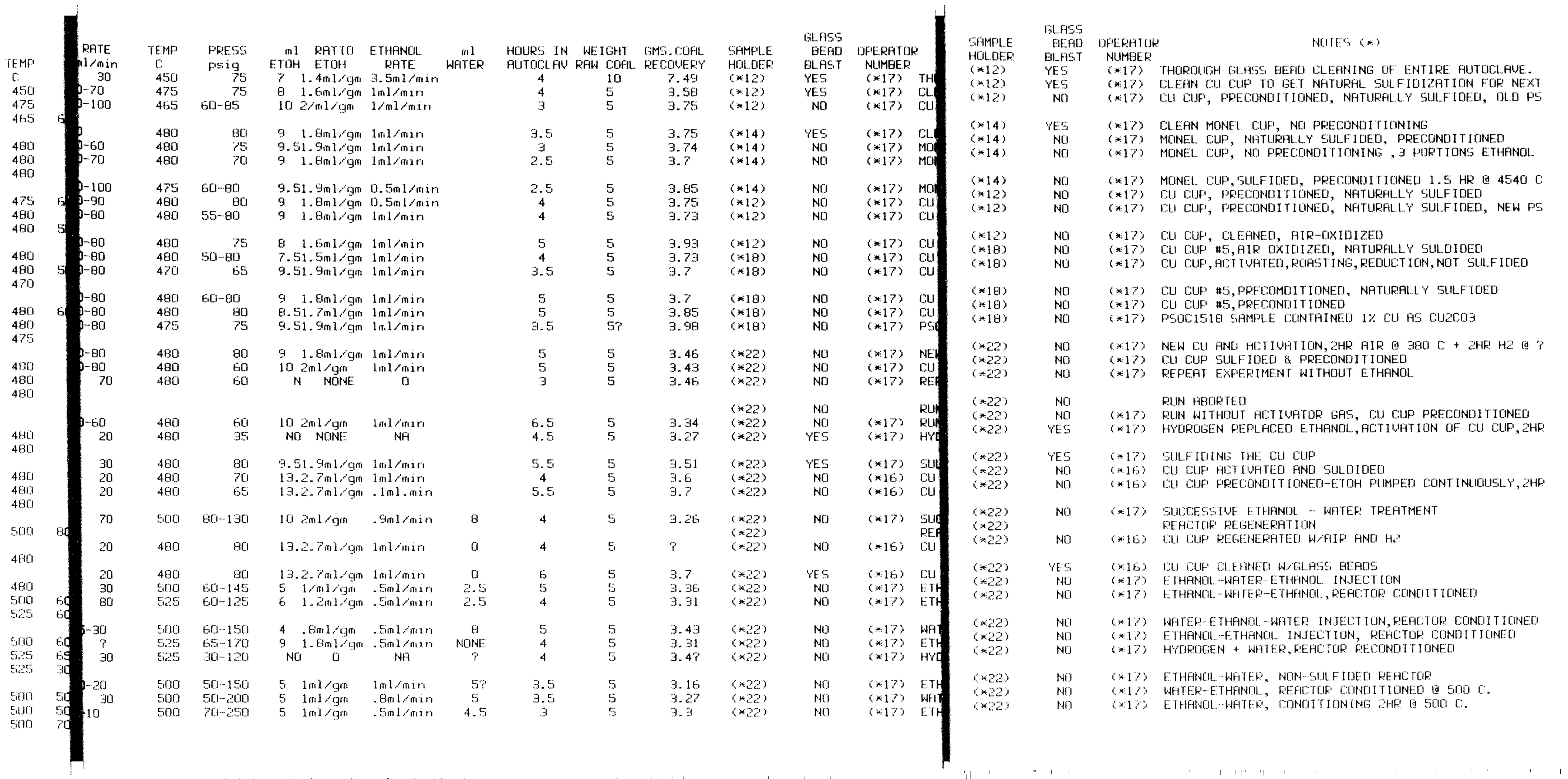




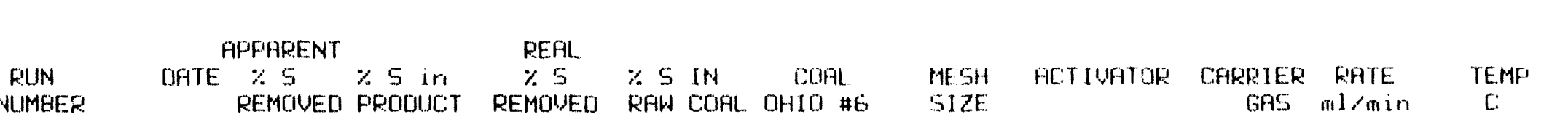

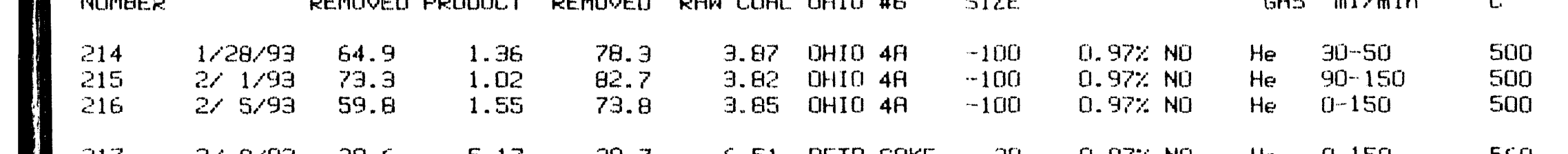

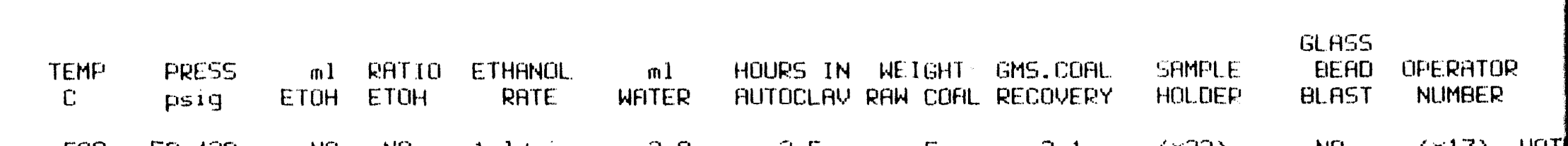

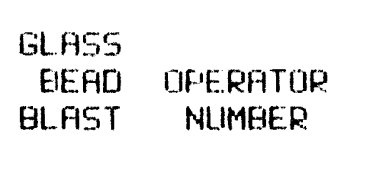

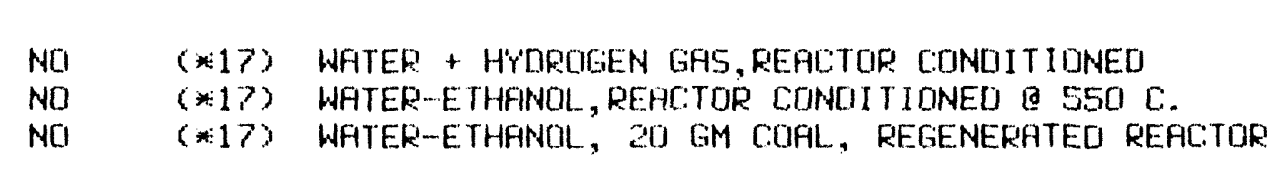

No
No
No

ANCL, REACTOR REEENERATED

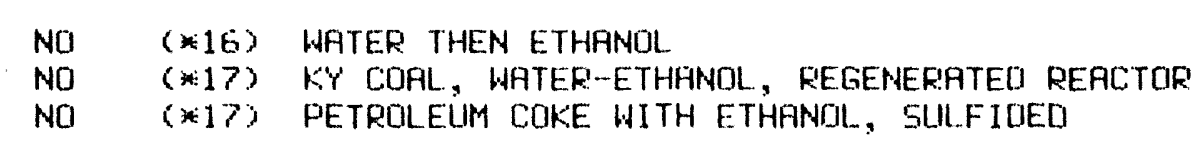

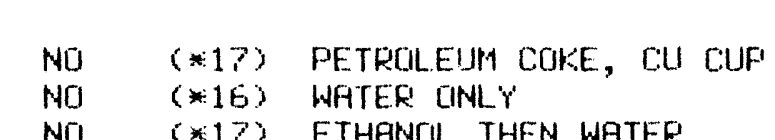

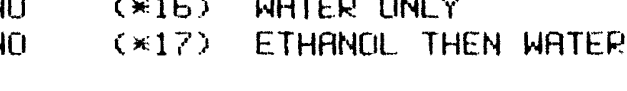

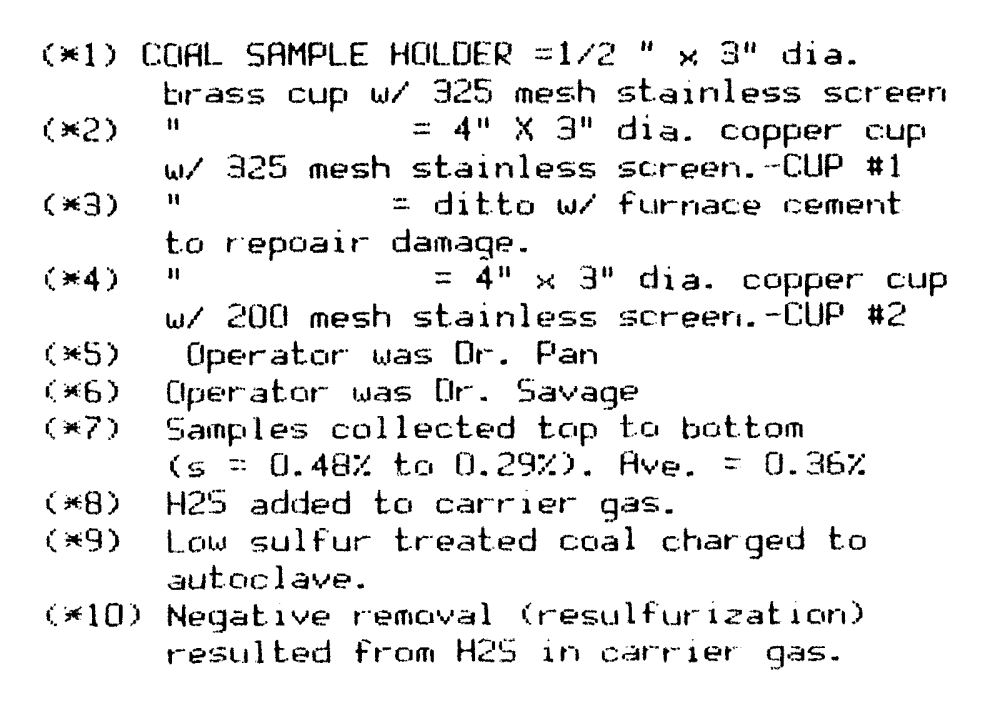

TER WITH ILLINOIS COALL

(*11) N.D. sampie holder, brass cup
below screen.
New copper cup from shiop. -Cup

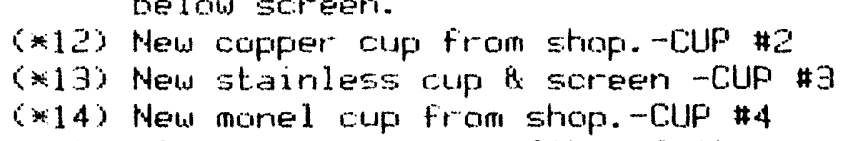

*15) Giass cup wo glass fiber filt
beaker in bat tom of autcal lave

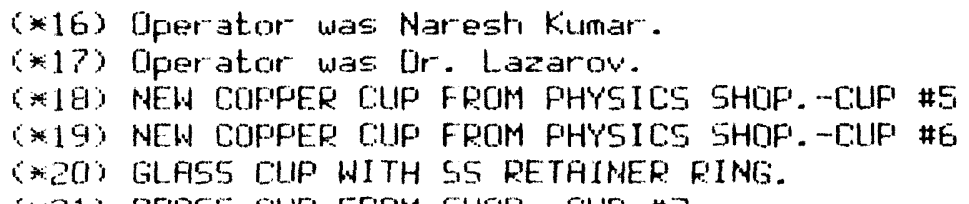

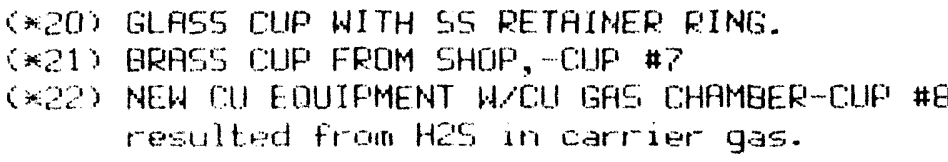



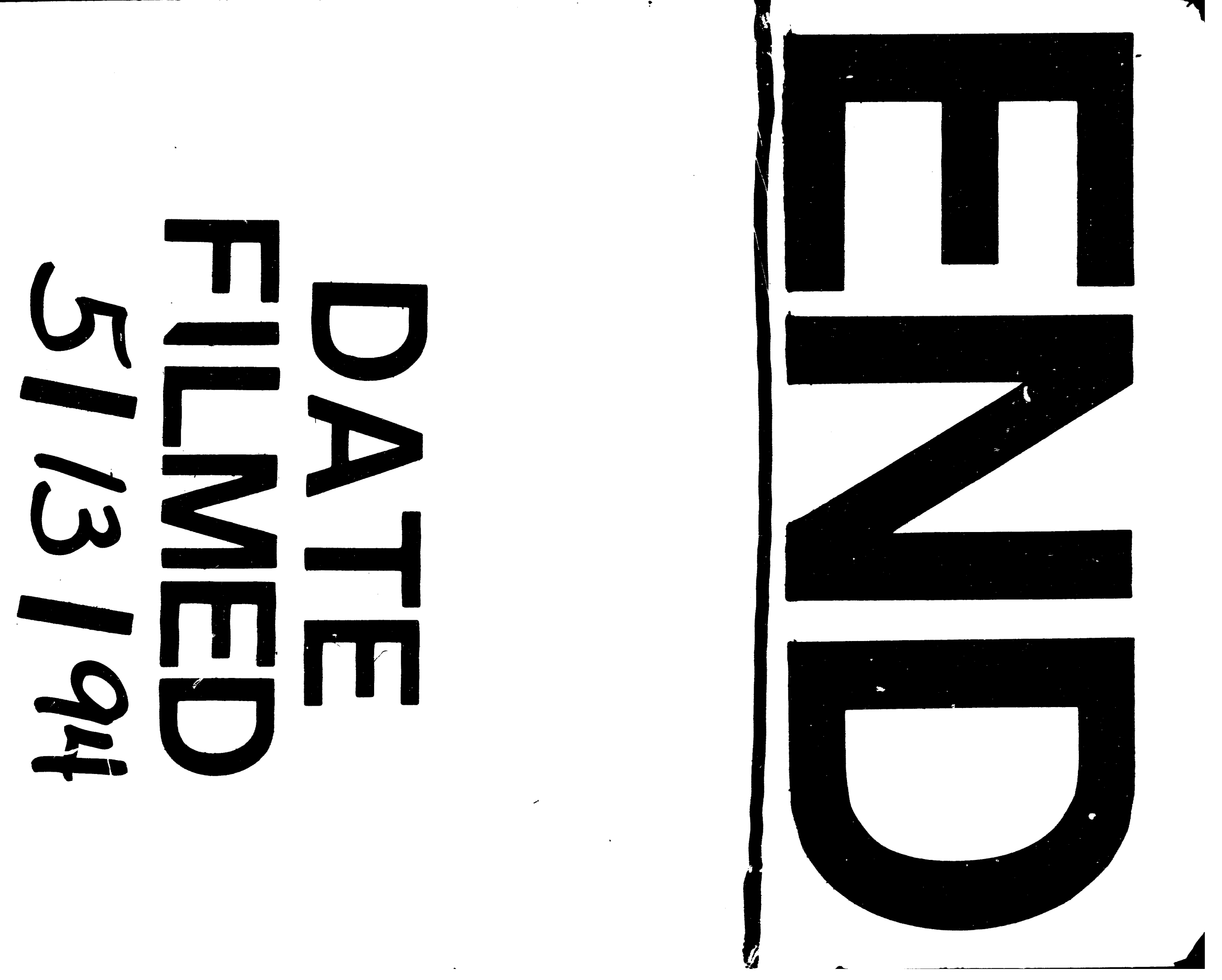